\title{
WAGE EARNER BANKRUPTCIES- STATE vs. FEDERAL CONTROL
}

\author{
WILLIAMT O. DOUGLAS †
}

I

THE great increase in recent years of the number of non-commercial, as well as commercial, bankruptcies ${ }^{1}$ is doubtless one reason why public and official attention has been directed to bankruptcy reform. But reformers for the most part have assumed that the bankruptcy power in all respects should continue to be exercised by the Federal government and have neglected to appraise the functions which bankruptcy performs or might perform in our economic order. Bankruptcy, like other institutions, has a curious way of becoming sufficient unto itself. Its functions, the problems with which it deals, its purposes, the relationships between it and current economic and social conditions are lost sight of or assume a minor position.? Attention, energy and resources are directed towards making the institution internally more efficient, so that its business may be expedited and its abuses eliminated. This is reflected in part by the not uncommon feeling that the pressing problem of bankruptcy is to remove ambiguities in various sections of the act so as to make bankruptcy a less confusing or less strenuous game. Or, again, the institution may be defended against all assault on the grounds that its heritage is so priceless, its age so venerable and its status so impregnable that nothing should be done to change its essential characteristics. This is reflected in the objection of the committee of the American Bar Association to recently proposed amendments to the bankruptcy act, that upon the present bankruptcy act,

iSterling Professor of Law, Yale University.

1. See Sturges, Credit Administration and Wage Earner Banleruptcics (1933) 42 Y ALE L. J. 487; and see Nugent, Why Wage Eamers Go Bankmupt (1931) 24 AMr. BK. Assoc. Jour. 9.

2. See especially Hearings Before a Subcommittee of the Committee on the Judiciary, United States Senate, 72d Cong., 1st Sess., Parts 1-4 inc., (Gov. Print. Off. 1932) on SEN. Doc. 3866 (the so-called Hastings Bill) introducing amendments to the Bankruptcy Act prepared and sponsored by the Department of Justice and recommended by the President. In this connection see Douglas, The Hastings Bill and Lessons Learned from the Banliruptcy Studies (1932) 7 JOUR. NAT. AsSOC. REF. IN BANKRUPTCY 25. 
"has been builded a great body of judicial decisions which must not bo destroyed or abandoned in favor of theoretical or untested innovations." J

Or, when economic and social disorders become acute, as at present, and bankruptcy is used more and more, and an increasing number of people fail to pay their debts, attempts to tighten-up on debtors are made. The institution becomes glorified in its efforts to counteract the tendency towards repudiation and non-payment of just obligations.

The efforts to improve bankruptcy have been great in scope and intensity in recent years. The work done has been of high calibre and scholarship. Yet to a great extent it begs the major and dominant aspects of the problem. Bankruptcy per se has its problems of organization and control as does any other judicial or administrative organization. But those problems are relatively insignificant as compared with conditions which give rise to the use of bankruptcy. In the medical profession great efforts and progress have been made in preventive as well as curative medicine. In the field of bankruptcy, however, the efforts have been otherwise. It would, of course, be ridiculous to suppose that bankruptcy experts could solve all the pressing problems of the present order. It is, however, to be regretted that when public funds and agencies of the United States government are mobilized under the direction of the President, the objective of the investigators should so completely disregard these pressing problems and center so largely upon the traditional theme of internal efficiency. ${ }^{4}$ It seems, moreover, not too extravagant to hope that bankruptcy can be viewed against the background of the conditions with which it deals; that long-term planning for the many separate problems can be made; and that in light of that planning the rôle or function of bankruptcy in the total program be determined. Such planning leads directly to a consideration of division of control and responsibility between state and nation as respects these various problems and of allocating or dividing between the two the bankruptcy power as an incident of that control. Congress has but little direct control over the economic and social problems within the various states. Yet through the exercise of its bankruptcy power given it by the Constitution ${ }^{\mathfrak{b}}$ it exerts an indirect but pervasive control over a wide variety of problems otherwise in the domain of the states.

The bankruptcy power in general entails a determination of legislative policy on two problems: (1) the collection and equitable dis-

3. American Bar Assoc., CommirTge ANd OTHer Reponts, 55th Annual Meoting, 1932, p. 89; and see the argument for substantive reform proposed by Professor James A. McLaughlin (1932) 11 CoNG. Dig. 177, 178.

4. See Strengthening of Procedure in The Judicial System, SEN. Doc. No. 65, 72d Cong., 1st Sess. (U. S. Gov. 1932).

5. Art. I, \& 8 (4). 
tribution of assets of a debtor among his various creditors; and (2) the release of a debtor from his legal obligation to pay his debts. More specifically the first problem requires a determination of when creditors may set the bankruptcy machinery in motion-how many creditors are necessary, the size of claims required, the nature of the claims, ete. Similarly, it requires a specification of assets of the debtor which may be reached, exemptions to which the debtor is entitled, priorities awarded to various creditors, and a host of details concerning the collection, liquidation, and distribution of assets.

The second problem entails primarily a determination of the debts from which a debtor may be discharged, the conditions if any for a discharge, and the grounds upon which it may be refused. Ancillary to this problem is the specification of conditions under which the debtor himself may initiate the proceedings against the will of his creditors in order to obtain the benefit of a discharge.

Congress has stated the policy on all these questions in the bankruptcy act now in force. And generally speaking, the enactment by Congress of such a comprehensive program is preëmptive in the sense that it supersedes or suspends state enactments in conflict therewith. ${ }^{\circ}$ It can readily be seen what a powerful instrument of control the bankruptcy power may become. It may or may not take cognizance of how the debtors became involved in debt and of the many differences between types of debtors. Or again it may or may not discriminate between types of creditors and make the discharge easily available against one type and more restrictive as respects another type. But little discrimination is shown under the present act between different types of debtors and creditors. ${ }^{\top}$ Yet it is apparent that if a system were provided which took cognizance of the many economic and social problems antecedent to bankruptcy, it would be possible to integrate the bankruptcy power into programs of social planning in many fields and to effectuate different policies for different problems depending upon their acuteness or importance in the several states.

\section{II}

It is the purpose of this essay to present in connection with two groups of wage earner bankrupts-one from New Jersey and the other from Boston ${ }^{8}$ - the variety and scope of the many economic and

6. See Boese v. King, 108 U. S. 379 (1883); International Shoe Co. v. Pinlius, 278 U. S. 261 (1928).

7. See Douglas, Some Functional Aspccts of Banlonuptcy (1932) 41 ThS I. J. 329.

8. The New Jersey cases were those filing bankruptcy petitions from the latter part of 1929 to the summer of 1930; the Boston cases, from the latter 
social problems antecedent to these bankruptcies and to show the desirability of relinquishing or leaving to the states the bankruptcy

part of 1930 to the summer of 1931. All of the Boston cases and about half of the New Jersey cases were studied by a personal interview followed or preceded by interviews with or letters from creditors and employers. The New Jorsoy cases represent about half of the wage earner bankruptcies in the district of New Jersey for the fiscal year ended June 30, 1930; the Boston cases about onefourth of the wage earner bankruptcies in the district of Massachusetts for the fiscal year ended June 30, 1931. The study in New Jersey took cases from all parts of the District of New Jersey-rural as well as urban. The study in Massachusetts took cases arising only in the metropolitan area of Boston, $i$. c., the counties of Suffolk, Norfolk, and Middlesex.

The New Jersey study was carried on with the genorous supervision and collaboration of Hon. William Clark of the United States District Court for tho District of New Jersey. The Boston study was made possible only becauso of the whole-hearted cooperation on the part of Hon. Arthur Black, Hon. B. Loring Young, and Hon. Charles C. Cabot-referees in bankruptcy in Boston.

Both the New Jersey and Boston studies were conducted jointly by the Despartment of Commerce, the Yale Law School, and the Institute of Human relations of Yale University. Dr. W. C. Plummer of the Wharton School of 'Commerce represented the Department of Commerce in the Now Jersey study; Mr. Victor Sadd in the Boston study. A report on the New Jersey business and -wage earner bankrupts has been made by Dr. Plummer. See Causes of Busi-ness Failures and Bankruptcies of Individuals in Nelv Jorscy in 1020-30, Domestic Commerce SerRes No. 54, Publication of the Department of Commerco (Gov. Print, Off. 1931). A report on the Boston business cases has been mado by Victor Sadd and Robert T. Williams. See Causes of Commercial Bankruptrcies, Domestic Commerce Series No. 69, Publication of the Department of Commerce (Gov. Print. Off. 1932). A report by the Department of Commerco on the Boston wage earners is forthcoming.

Most but not all of the wage earner cases discussed herein are included in ithe foregoing reports.

By occupation these wage earners were distributed as follows:

\begin{tabular}{|c|c|c|c|}
\hline & & tions & \\
\hline & & Boston & New Jersey \\
\hline & Skilled & 88 & 31 \\
\hline & Unskilled & 26 & 6 \\
\hline$r$ & Sales & 81 & 22 \\
\hline - & Office & 26 & 7 \\
\hline$\cdots$ & Public & 22 & 9 \\
\hline & Professional & 8 & 15 \\
\hline$\cdots$ & Executive & . 31 & 3 \\
\hline$=$ & Housewife & 4 & 8 \\
\hline & None & 1 & 0 \\
\hline & Unknown & 14 & \\
\hline & & 301 & 107 \\
\hline
\end{tabular}

The Attorney General's Report lists the professional group separately. They have been added here partly for convenience due to the small size of the group and largely because all but a very few were in fact on salaries. Housowives 
power over such cases. In such a way basic differences in types of problems can be recognized by the several states and the bankruptcy power can be exercised so as better to effectuate any state program of control over a particular problem.

Determination of causes of bankruptcy is extremely hazardous. Post mortems in this field are none too successful. Cause and effect curiously intermingle. Cause here, as in other situations such as automobile accidents, would appear differently to different observers. Further, the train of events during the months preceding bankruptcy is difficult to reconstruct. In most cases, however, a dominant characteristic does appear. These characteristics are many and varied. Only general or gross classifications will be made here. But from them will emerge some picture of the wide variety of social and economic problems with which bankruptcy deals. Against the immobility of the institution of bankruptcy and its uniformity may be set the mobility and lack of uniformity of the situations with respect to which it functions. And when it is remembered that commercial, industrial, and social problems vary much from state to state and from region to region, the conviction grows that this national and uniform system of bankruptcy cannot be made sufficiently flexible to give expression to policies respecting so many varied problems.

have also been added for the same reasons; and the "none" group breause of the small size. Housewives, "none," and unknown probably appear under the heading "Other classes" in the reports of the Attorney General. At least from our study of classifications of bankrupts made in another connection that was true. See Strengthening of Procedure in The Judicial System, supra note 4, at 157, setting forth the results of our break down of "Other classes."

Our classification "Public" includes policemen, firemen, mail carriers, sherifts, and higher governmental employees; "Executive" includes department heads and other junior, as well as senior, executives.

On nationality the following is the classification of the Boston bankrupts, considering a person an American if both he and his father were born in the United States and as an alien if he or his father were born in a foreign country: American, 135; Russian, 33; Canadian, 30; Scotch, 19; Irish, 18; German, 15; English, 13; Italian, 13; Others, 29.

The age distribution of the Boston bankrupts was:

\begin{tabular}{lr} 
Under 30 & 37 \\
$30-39$ & 110 \\
$40-49$ & 78 \\
$50-59$ & 53 \\
60 and over & 16 \\
\multicolumn{1}{c}{ Total } & -294
\end{tabular}

281 of the Boston bankrupts were males; 20 , females. 
Personal bankruptcies are often attributed in popular thought to too much consumption credit. The element of "too much" is usually present. But whether it is always or normally consumption credit may be wondered. Consumption credit and its incidence in bankruptcy are difficult if not impossible to measure. Using, however, as the measuring rod of consumption credit, amounts owed to loan companies, on instalment purchases, and on retail open accounts the following observations may be made.

Ninety-six of the Boston group owed loan companies. The average amount owed was $\$ 651$, as against the average of all liabilities in these cases of $\$ 6474$. Forty-five of the New Jersey group owed such companies, the average amount owed being $\$ 1466$ as against the average of all liabilities in those cases of $\$ 19460$. The loans were made for many different reasons-to pay doctors, to buy automobiles, to make payments on a home, to pay tuition in a night school, to buy clothes, etc. Nor was any one purpose dominant, or more prevalent than another.

In the 96 Boston cases there were 54 different loan companies and 20 credit unions with claims. Eighteen of these loan companies were unlicensed and operating outside the law which makes illegal interest in excess of $31 / 2 \%$ per month on unpaid balances of loans of $\$ 300$ or less. Twenty-five of the 96 bankrupts owed these 18 unlicensed companies.

Pyramiding of loans was not conspicuous as seen from the following table:

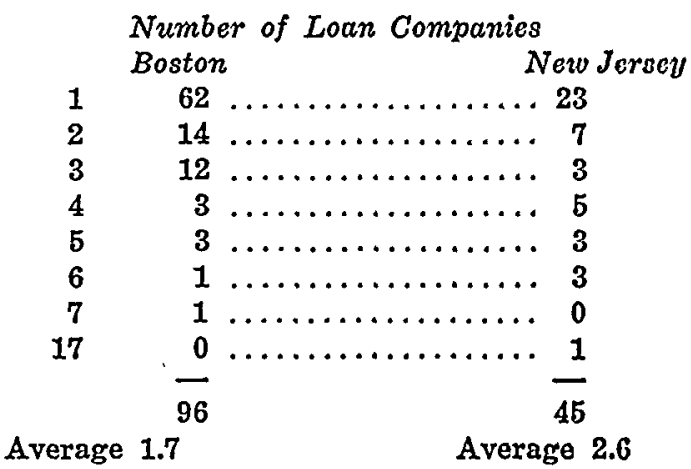

As can be seen almost two-thirds in Boston and over one-half in New Jersey owed but one loan company. Instances of many loan companies, so prevalent in other studies, ${ }^{9}$ are inconspicuous in the Boston cases and not predominant in the New Jersey ones.

9. See e.g., Fortas, Wage Assignments in Chicago-Stato Strect Furnituro Co. v. Armour \& Co., (1933) 42 Yale L. J. 526, passim. 
There were only 11 of the Boston cases and 5 of the New Jersey cases where the amount owed loan companies was $50 \%$ or more of all liabilities. In 7 of the 11 Boston cases and in two of the New Jersey cases the indebtedness to loan companies constituted all or practically all of the total liabilities.

There were 90 of the Boston group who owed balances on instalment purchases. The average balance owed was $\$ 532$ as compared with the average of all liabilities in those cases of $\$ 18,233$. The range of instalment debts was from $\$ 11$ to $\$ 8500$. The purchases usually were clothes, furniture, and automobiles. But in only 19 of the group of 90 were such debts $50 \%$ or more of the total liabilities. And in but 3 of the 19 were those debts all or practically all of the liabilities. There were only 5 cases in the New Jersey group oving debts on instalment accounts. These debts were so small as compared with the total liabilities that they have been eliminated here from further consideration.

Of the Boston cases 214 owed retailers, the average amount owed being $\$ 466$ as against an average of total liabilities in those cases of $\$ 8,713$. In only 34 of those cases were retail debts $50 \%$ or more of the total liabilities and in only 13 did they constitute all or practically all of the liabilities.

Combinations of debts owed loan companies and retailers on open and instalment accounts will be considered later in respect to certain types of cases. To recapitulate here, the relation of these debts (1) to total liabilities in those cases and (2) to total liabilities in all the cases might be summarized as follows for the Boston cases:

$\begin{array}{lcccc} & \text { No. Cases } & \text { Amount } & \begin{array}{c}\text { \% Liab.in } \\ \text { These Cases }\end{array} & \begin{array}{l}\text { \% Liab.in } \\ \text { All Cases }\end{array} \\ \text { Loan Companies } & 96 & \$ 62,496 & 10 \% & 1.5 \% \\ \text { Instalment } & 90 & 47,880 & 2.8 & 1.1 \\ \text { Retail } & 214 & 99,830 & \frac{5.3}{18.1 \%} & \frac{2.8}{5.4 \%}\end{array}$

And the number of cases in the Boston group where the amount owed loan companies, or retailers on open or instalment account was $50 \%$ or more of all liabilities in these cases may be summarized as follows:

$50 \%$ or more

Iroan Companies

Instalment

Retail

Total $\quad \frac{34}{64}$
All or practically all

\begin{tabular}{rr}
11 & 7 \\
19 & 3 \\
34 & 13 \\
\hline 64 & 23
\end{tabular}


If consumption credit is measured in terms of amounts owed loan companies and retail stores on instalment and open account, its incidence in these bankruptcy cases is not great, certainly as respects the total of all cases. It seems obvious that these bankrupts are not dominantly composed of victims of moneylenders or of those who have overindulged in instalment or other retail credit. The incidence of consumption credit in particular cases will be examined more in detail hereafter. In general it may be concluded that consumption credit is cumulative rather than direct in its effect on these bankruptcies.

-We know, however, that in some districts the relationship between consumption credit and bankruptcy is intimate..$^{10}$ Complexion and practices of loan companies vary much from state to state and even within states. Retail credit practices are by no means standardized. And controls by creditors over the flow of credit are also variable. Industrial and social conditions contribute to the resultant nonuniformity in quality and quantity of consumption credit. Some states are active in their control over these problems; some are not. Bankruptcy of course increases in importance as the problems of consumpton credit become more acute. As state regulation of these businesses and their practices advances it seems essential that the possibilities of bankruptcy as an integral part of that control be evaluated. In terms of social planning it seems essential that the bankruptcy power be vested in the hands of those who otherwise control these agencies of consumption credit. That would entail a surrender of the power by Congress and its return to the states. Thereupon it could be employed by the states as an integral part of their multiple program of control over such businesses.

\section{Excessive Expenditures Without Mitigating Circumstances}

Expenditures in relation to income are by no means a criterion for classifying bankrupts. Income may have been reduced so low that expenditures for necessities of life may appear to be extravagant. Housing conditions may warrant and justify the payment of a disproportionate amount of income for rent. Sacrifices of some items may permit indulgence in luxuries; and so on. In making this classification regard has been had for minimum standards of living, for income, and for dependents; and in light of those, expenditures have been judged. But even so, some cases were marginal or doubtful. Taking only those cases reasonably free from doubt, there are 32 from the Boston group and 12 from the New Jersey group where, without any mitigating circumstances, expenditures preceding

10. See Nugent, Consumer Credit and Social Agencies (1931) 42 U. S. INVESTOR 14, 16, describing conditions in Kentucky. 
bankruptcy seemed clearly excessive, not including the cases of home building and buying discussed hereafter.

Most of these were not cases of fraud in the usual meaning of the term. Not over six were cases involving an element of intent to deceive and to obtain goods without paying for them. The balance were cases of irresponsibility and excessive optimism as to the early arrival of prosperity. Ten were cases of overindulgence in expensive cars. The others were splurges in high class apartments, jewelry, fur coats, furniture, radios and similar articles. Six were cases of extravagant wives from whom the debtor had been separated or divorced, the debts being incurred at the time of the domestic trouble.

There were 17 others from Boston which were marginal or doubtful cases. Making an es post facto judgment it was impossible to weigh certain possibly mitigating circumstances such as medical costs, reduction of salary, an automobile accident, an accommodation note, an increase in number of dependents, etc. These 17 were not cases of fraud. They were irresponsibility plus. The intervention of illness and medical costs was present in 9 of them; unemployment or reduction of income in 5 ; and automobile accident judgments in 3. Conservatively, then, 32 of the Boston cases would be classified here; liberally, 49.

In the 49 Boston cases the average of liabilities was $\$ 2,460$, the range being from $\$ 400$ to $\$ 8,500$. The New Jersey cases were of about the same complexion and owed about the same amounts.

Of the Boston cases, consumption credit (as measured by debts to loan companies and to retailers on open and instalment account) is more conspicuous in this group than in any other. $\$ 7,919$ was owed to loan companies, $\$ 9,268$ on instalment purchases, and $\$ 32,187$ to retailers on open account. The total of $\$ 49,374$ was $41 \%$ of all the liabilities in those cases. Or, out of the total of debts owed loan companies in all cases $12 \%$ was owed by the cases of this group, $19 \%$ in cases of instalment debts; and $31 \%$ in cases of retail debts on open account.

There were, of course, cases of abuse of consumption credit in this group. In 28 of the 49 Boston cases such debts were 50\% or more of the total liabilities; and in 12 cases these debts constituted all or practically all of the liabilities. And while 7 of the $12 \mathrm{New}$ Jersey cases owed loan companies, only one owed any substantial amount and in that case such debt constituted all of the liabilities. Abuse of consumption credit then was hardly a dominant characteristic of the cases of either group. In other words there are many ways of being extravagant besides indulging in small loans, instalment purchases, and ordinary retail credit. Yet from these 
cases it may be wondered just how intimate the relationship between abuse of consumption credit and bankruptcy is.

Case 0880, a middle aged skilled workman, up to three years ago had been making around $\$ 5,000$ a year. Since then his earnings had dropped to around $\$ 2,000$ due to curtailment of production and business depression. His debts were scheduled at $\$ 1,600$ and his assets as $\$ 8$ in cash. $\$ 1,000$ was owed retailers and $\$ 300$ to the landlord. His rent was $\$ 900$ a year-almost half of his income. Following reduction in salary, he and his wife did not readjust their scale of living. Unknown to the bankrupt his wife had opened up new accounts in Boston department stores during the last year. Likewise she purchased an automobile for $\$ 350$ on instalment. The bankrupt blamed not his wife but the "loose credit practices" of Boston department stores.

Salesman 0863 , aged 51, had assets of $\$ 36$ and liabilities of $\$ 8,500$. His earnings had been as high as $\$ 7,500$ but during the last year had dropped to $\$ 3,500$. His first wife divorced him the year previous and was granted $\$ 3,000$ a year alimony. He also acquired $\$ 1,000$ of her debts. But the second wife was more expensive. He purchased a $\$ 200$ car for his second honeymoon. She became ill and he spent $\$ 450$ on her for doctor's bills. In addition he borrowed $\$ 500$; charged $\$ 2,300$ for flowers, fur coats, groceries; $\$ 400$ for hotels; $\$ 225$ for rent; $\$ 439$ for the lawyers who defended his case. There also were earlier loans of $\$ 4,000$. At the time of the examination the second wife was confined in a psychiatric ward in a famous hospital and salesman 0863 was complaining of a "nervous ailment." Through all this time, however, he had paid regularly the $\$ 300$ annual premiums on his life insurance.

Case 0389 had been with his present employer twenty years and had worked up to a position of foreman in the factory. He earned $\$ 1,500$ a year and his employment was full time. He had always been able to make ends meet and had a good record of honesty and dependability. He had a wife and five children and three years earlier had purchased a house on mortgage for $\$ 3,500$, the carrying charges being about $\$ 450$ a year. At the same time he purchased on instalment an automobile for $\$ 500$. Shortly thereafter his daughter aged 14 married a boy aged 17. The boy had no employment or means of support. Accordingly he and his wife moved in with the bankrupt who paid all the expenses. The necessity of supporting eight people proved an enormous burden. Another daughter grew up and she, her married sister and the bankrupt's wife began to increase the standard of living. Their bills for cold creams, powders and perfumes were $\$ 15$ a month. They purchased $\$ 1,200$ of furniture, radio, and clothes on instalment. $\$ 700$ was borrowed 
from loan companies to meet instalments on the auto and on the house and for additional luxuries. The unpaid grocery bill mounted to $\$ 450$. The payments on the house were defaulted and the mortgage was foreclosed. The car was repossessed. The demands of the eight dependents for luxury and entertainment continued. The total liabilities were $\$ 2,700$, almost two years' salary of the bankrupt. His wages were attached and to keep his job he filed the voluntary petition.

\section{Rent}

Rent as an item of expenditure should be considered perhaps in connection with the foregoing group of cases. From a study made in 1918 by the Bureau of Labor Statistics of the United States Department of Labor of the cost of living in 92 industrial centers, including Boston, 11 the average family of five with income below $\$ 2,100$ a year spent between $13 \%$ and $15 \%$ of the annual income for rent. When the income was in excess of $\$ 2,100$, the amount spent for rent was between $10 \%$ and $12 \%$.

A study made in 1930 of the standard of living of Ford employees in Detroit with an average income of $\$ 1,700$ and families of 4.5 persons ${ }^{12}$ showed the amount spent for rent about $23 \%$ of income. ${ }^{13}$

And from a study made in Boston in 1928 of the cost of living of federal employees ${ }^{14}$ with an average family of $4.1^{15}$ persons and earning not over $\$ 2,500$ a year the average amount paid for rent each year was $\$ 500$. The percentage of annual income paid for rent probably ranged from $33 \%$ or slightly more in the lower income brackets to around $20 \%$ in the higher income brackets.

Compared with these studies is the estimate made in 1927, that $\$ 30$ a month was necessary for "the average minimum expenditure for rent in Boston for the family of four living on an American standard." 16

A detailed analysis of the Boston bankrupts in this connection will not be set forth here. But the following summary is interesting as showing the importance of the rent item, certainly in the

11. Cost of Living in the United States, Bull. No. 357, Bureau of Labor Statistics, U. S. Dept. of Labor (1924).

12. Standard of Living of Employees of Ford MLotor Co. inz Detroit (1930) 30 RIONTHLY LABOR REviEw 1209 et seq.

13. $22.6 \%$ of the average yearly expense. The average deficit for all families was $\$ 7.96$.

14. Cost of Living of Federal Employees in Five Cities (1929) 29 MIONTHLY LABOR REVIEW 315 et seq. The other cities were Baltimore, Chicago, New Orleans, and New York City.

15. Not including boarders and lodgers.

16. The Cost of Living in Twelve Industrial Cities, Natural Industrial Conference Board (1928) at 21. 
lower income groups. It should be noted, however, that the precise extent to which drastic reductions in income, especially in the lower income groups, have resulted in disproportionate expenditures for rent cannot be computed.

$\begin{array}{lcc}\text { Income } & \text { No. of Cases } & \text { Average \% Rent of Income } \\ \$ 1,000 \text { or less } & 38 & 92 \% \\ \$ 1,500 \text { and over } \$ 1,000 & 56 & 34.9 \\ \$ 2,000 \text { and over } \$ 1,500 & 50 & 27.5 \\ \$ 2,500 \text { and over } \$ 2,000 & 22 & 22.9 \\ \$ 3,000 \text { and over } \$ 2,500 & 9 & 27.5 \\ \text { Over } \$ 3,000 & 11 & 16.1 \\ & \text { Total Cases }-\frac{186}{18} & \end{array}$

Taking arbitrarily $33 \%$ and $20 \%$ as measurements of reasonableness of rent, the following distribution of cases above and below those standards appears:

\begin{tabular}{lcccc} 
Income & Over $\$ 3 \%$ & $\$ 3 \%$ or less & Over $20 \%$ & $20 \%$ or less \\
$\$ 1,000$ or less & 37 & 1 & 38 & 0 \\
$\$ 1,500$ and over $\$ 1,000$ & 28 & 28 & 47 & 9 \\
$\$ 2,000$ and over $\$ 1,500$ & 12 & 38 & 36 & 14 \\
$\$ 2,500$ and over $\$ 2,000$ & 0 & 22 & 16 & 6 \\
$\$ 3,000$ and over $\$ 2,500$ & 3 & 6 & 6 & 3 \\
Over $\$ 3,000$ & 0 & 11 & 3 & 8 \\
\cline { 2 - 3 } & 80 & 106 & 146 & 40
\end{tabular}

Liability for rent was not conspicuous, however, in the Boston bankruptcies. There were $78(26 \%)$ who had such debts among their liabilities. These owed on the average $\$ 421$, the range being from $\$ 20$ to $\$ 1,500$. These debts were negligible as respects the total liabilities in those cases and almost infinitesimal in the total liabilities of all cases. In only 9 cases was the rent liability $50 \%$ or more of the total liabilities, and in only 1 case did it amount to all or practically all of the liabilities.

Here are then a considerable group of cases reflecting through the medium of rent a variety of situations. It is not apparent that extravagant living is necessarily proved. Long term leases signed in times of prosperity take their toll in periods of depression. Housing conditions, especially for lower income groups, vary much from city to city and state to state. Social standards likewise vary and in any one place are relative. In dealing with the item of rent then in bankruptcy, as well as in budgets, we are dealing with an indicator that at times points to cause and at times to effect. Like bankruptcy it is a mirror reflecting many different social and economic conditions. 
Seventy-six of the Boston bankrupts had made attempts at buying or building their own home. In all but three of these cases the mortgage had been forclosed. Sixteen had made the purchase in their wives' names. The average term of the venture was a little over a year. Payments of interest and amortization of principal were on the whole out of all proportion to the annual income. The following table shows that proportion. The extent to which drastic reductions in income, especially in the lower income groups, have resulted in disproportionate expenditures cannot be accurately computed.

$\begin{array}{lcc}\text { Annval Income } & & \begin{array}{c}\text { Average \%o } \\ \text { No. of Cascs }\end{array} \\ \$ 1,000 \text { or less } & 16 & 176.7 \% \\ \$ 1,500 \text { and over } \$ 1,000 & 8 & 71.9 \\ \$ 2,000 \text { and over } \$ 1,500 & 15 & 40.0 \\ \$ 2,500 \text { and over } \$ 2,000 & 9 & 40.7 \\ \text { Over } \$ 2,500 & 10 & 23.0 \\ & \text { Total }-58 & \end{array}$

These ill advised attempts at home owning accounted for 40 of the Boston bankruptcies. In many others it contributed to the load of debts. But those have been eliminated here. These 40 are cases where either the intervention of subsequent disasters such as unemployment, sickness, etc. merely accelerated the end of a doomed venture; or where such intervening factors were not present. One example of the former is the purchase of a house calling for yearly payments of $\$ 1,000$ a year for ten years. The purchaser at the time was making $\$ 3,100$ a year and had eleven people totally dependent on him. The same year his salary was reduced to \$2,250; he defaulted in his payments; the mortgage was foreclosed and a deficiency judgment of $\$ 3,000$ was entered against him. Another was the purchase of a home requiring payments of $\$ 1,400$ a year. The purchaser's annual salary was $\$ 2,100$ and he had five dependents. He only paid $\$ 600$ when foreclosure was had. Meanwhile his salary had decreased through lay-offs to $\$ 1,600$ ' a year. An example of the latter was the purchase of a home for $\$ 6,400$ with annual payments of $\$ 800$ by a man earning $\$ 2,200$ a year and having four dependents. The house was in such poor condition that it was necessary to borrow $\$ 2,000$ to make it livable. The mortgage was foreclosed and the total liabilities were the $\$ 2,000$ borrowed.

In all but four of the cases deficiency judgments had been entered. In the four the property had been foreclosed and the amount owing was for money borrowed either to repair the house or to pay taxes 
and meet payments under the mortgage. In one case $\$ 4,500$ had been borrowed from five different loan companies.

In all of the 40 cases the deficiency judgment or amount borrowed to finance the house constituted all or practically all of the liabilities. The average amount owed was $\$ 7,871$, the range being from $\$ 546$ to $\$ 50,000$.

To these 40 may be added 11 from the New Jersey group, the average here owed being $\$ 7,294$, the range being $\$ 1,000$ to $\$ 20,000$.

Financing of home building or buying is essentially a local problem in which savings banks, commercial banks, building and loan associations, etc., all play a part. The intrusion of the Federal government in this field in recent years can hardly be taken as indicative of a preëmptive program on its part. Home building and buying, as well as housing, seems so articulated with municipal affairs that it will remain essentially a local problem, ${ }^{17}$ inseparable from the problem of taxation and the methods of promotion, appraisal, financing, and collection. If the above data are representative, the relationship between home building and bankruptcy is by no means inconsiderable. Bankruptcy looms as an effective agency for control of these problems. The possibilities of its use as such have never been exploited or tried. Nor can they be, so long as the power rests in Congress whose opportunity for long term planning and intimate control in this field is exceedingly indirect. A return of the bankruptcy power to the states makes possible a utilization of this power in any program for social planning in this field. The futility of uniformity is avoided. The adaptation of the power to changing and variable conditions from state to state becomes possible.

\section{Speculation and Gambling}

Fifteen of the Boston bankrupts went into bankruptcy solely as a result of speculation in realty. Five of these were aftermaths of the collapse of the spectacular Florida boom. In the fourteen cases there were practically no claims among the liabilities except those arising out of the speculation. Those claims ranged from $\$ 988$ to $\$ 177,000$, averaging $\$ 27,893$.

Mechanic 0881 making $\$ 3,000$ a year and having steady employment acquired eight houses during the last three years. His wife managed them. A year ago she died. He did not have the time to attend to them. He began to lose tenants. Then came the real estate slump. All mortgages on the eight properties were foreclosed and

17. See Reports of The President's Conference On Home Building and Home Ownership, vols. II, IV, and XI (Wash. D. C. 1932). 
deficiency judgments of $\$ 50,000$ entered against him. These constituted all of his liabilities. His assets were zero.

Five of the New Jersey bankruptcies were the result of real estate speculation. The liabilities ranged from $\$ 2,000$ to $\$ 25,000$.

Seven others from Boston came into bankruptcy as a result of stock speculations; and five more as a result of gambling with cards, dice and lottery tickets. The average debt was $\$ 8,755$. A review of many of these cases has been given elsewhere. ${ }^{18}$ The following are somewhat typical.

Case 0696 was a laborer earning $\$ 35$ a week. His wife received $\$ 15$ a week for stenographic services. They purchased a home for $\$ 5,700$, the carrying charges being about $\$ 75$ a month. They secured access to a source of market "tips." They were wiped out by the stock market crash, losing about $\$ 5,000$. They struggled along for a while. On a Saturday they appeared at a retail house and purchased $\$ 75$ of goods on credit. On Monday next the petition was filed. In spite of the heavy losses and low income the debts exceeded the assets by less than $\$ 2,000$, most of which was owed commercial houses.

Case 0255 was a laundress making $\$ 33$ a week. She had accumulated over a period of years $\$ 5,000$ in savings. This was used in the fall of 1928 to purchase two well known stocks on margin. In the stock market crash the stocks dropped about forty points each, wiping her out and leaving a balance of $\$ 600$ due the broker. Suit was brought for that sum. That claim represented all of her liabilities. Her assets were zero.

Of the New Jersey cases five came under this head.

\section{Accommodation Indorsements}

Debts on accommodation indorsements of notes were present in 52 of the salaried group of Boston bankrupts. The average debt on indorsements was $\$ 16,292$, the range being from $\$ 45$ to $\$ 400,000$. The average of all liabilities in those cases was $\$ 24,473$. Eight cases involved indorsements of notes to loan companies for friends and relatives. Eleven were indorsements in connection with a previous unsuccessful business venture of a relative or of a corporation with which the wage earner had been associated. One was the indorsement by a wife of $\$ 53,000$ of her husband's notes given in a number of speculative real estate transactions.

In over half (29) of the cases the debts on the indorsements constituted $50 \%$ or more of the total liabilities. In 15 such liability was all or practically all of the total indebtedness. In those cases

18. Douglas op. cit. supra note 7 , at 343. 
the debts for indorsements ranged from $\$ 250$ to $\$ 400,000$. In the 29 cases it is clear that the motivation for bankruptcy was the accommodation liability. In the remaining 23 , bankruptcy might well have followed even though no such liability was present. It is true that most of the group had a different attitude towards these obligations than towards other types of creditors. Yet a conservative estimate is that in only 29 cases were accommodation indorsements the sole factor in the bankruptcies.

To these might be added the case of an office employee earning $\$ 2,100$ who acted as a "straw man" 18 in a building contract. Out of that venture arose debts of $\$ 248,122$ which he went into bankruptcy to have discharged.

Accommodation indorsements were even more conspicuous in the New Jersey cases, 35 out of the 107 having such debts. The average debt on indorsements was $\$ 48,421$ as against the average of all liabilities of $\$ 49,870$. The range of 'indorsement debts was from $\$ 800$ to $\$ 300,000$. In five of the cases the indorsements were on notes of loan companies. The balance were in connection with a previous unsuccessful business venture of a friend or relative or of a corporation with which the bankrupt had been associated. In 31 of the cases the liability on indorsements was $50 \%$ or more of the total liabilities; and in fact constituted all or practically all of the liabilities: In every case the pressure of the creditor who held the indorsement was the direct occasion for the filing of the bankruptcy petition.

19. On "strawmen" see.Ottman v. Nixon-Nirdlinger, 301 Pq. 234, 151 Atl. 879 (1930); Rader v. Bernstein, 15 Pa. D. \& C. 341 (1931); Dietz v. Girard Craftsman's Club of Philadelphia, 9 Pa. D. \& C. 805 (1927); Squire v. William S. Drozda Realty Co., 288 S. W. 988 (Mo. App. 1926). In the Ottman caso a lessor of realty sued to recover overdue instalments of rent. The lessee had assigned the lease under seal to a strawman acting for defendnnts. The court reversed a judgment for defendants, holding they were undisclosed principals and liable on the basis of privity of estate. The dissenting judges said (p. 245) : "The effort of the law should always be to keep pace with the customs of the people, and this is practically so in the realm of trade. Of recent years, the attempt has been made to make the buying, selling, and ownership of real estate as easy and uncomplicated as that of other classes of property; the right use of strawmien facilitates this commendable end, and has been sanctioned by us."

In the Dietz case a corporation in order to make bonds legal investments for trust funds [PA. CoNST. Art. 3, § 22] conveyed its property to a strawman who executed mortgages on the property and issued bonds thereunder. Thereupon he reconveyed the property to the corporation "subject to" the mortgages. Subsequently the mortgages were foreclosed and a receiver was appointed for the corporation. The third mortgagee then asserted a claim against the assets of the corporations. The claim was disallowed. 
Case 0706 was sixty years old, rheumatic and an invalid, supported by his wife who ran a small candy shop and had \$50 income per month from a house she owned. He became accommodation comaker for a friend on a note for $\$ 375$. This was all of his liabilities. He had been ordered by the Poor Debtor Court to pay $\$ 2.00$ a week and was in contempt.

One employer in Boston allowed his employees two trusteeships of wages each year and no more. They were warned that if more than that number were filed, discharge might follow. Case 0661 had become accommodation co-maker or indorser on notes for friends to six different loan companies on eight different loans totalling $\$ 760$. His total liabilities were only $\$ 1,000$ including the above. None of these loans were for his use. The bankrupt was. earning $\$ 1,800$ a year and had regular employment. He was frugal and industrious and lived within his means, supporting a wife and one son. There was no other occasion for his bankruptcy. During the last year defaults were made on the notes and he made several payments. To avoid pressure of creditors and violation of the rule of his employer he filed his petition.

\section{Automobile Accident Judgments}

Five of the Boston cases came into bankruptcy as a consequence of automobile accident judgments. In addition to these five were six others who had among their liabilities judgments for such claims. Such judgments, however, were much more conspicuous among the New Jersey group, being present in 22 of the cases. In fifteen of those cases the judgment was over $75 \%$ of all the liabilities. The judgments covered property damage, personal injuries, and death.:0

Automobile accident judgments are dischargeable in bankruptcy..$^{21}$ The function of bankruptcy in that regard has been discussed elsewhere. ${ }^{22}$ The extent to which Congress should go in relieving judgment debtors from such liabilities is at best arguable. The relevancy of the data here is not so much to the function of the discharge and the social policies involved in relieving or not relieving debtors from such judgments as to the decidedly local nature of the problem of regulation of the automobile. Massachusetts since January 1, 1927 has had a compulsory automobile insurance statute. ${ }^{23}$ New Jersey has none. The whole problem of socializing the losses resulting

20. For a more detailed discussion of these cases see Douglas, op. cit. ouspro note 7 , at 340 .

21. See cases cited infra note 50 .

22. See Douglas, op. cit. supra note 7.

23. IIASS. Cum. StAт. (1927) c. 90 , $\S 34$ a et seq. 
from such accidents is far advanced in thought and discussion.24 The next decade will doubtless see much activity on the part of states to solve the problem. Yet judged from the past ${ }^{25}$ such legislation is not likely to be uniform in either scope or detail. Though in theory the problem is the same from state to state, actually conditions vary much, at least in intensity.

In other words the problem of the automobile accident judgment may well continue to vary much from state to state because of lack of uniformity 'both of conditions and of legislation. Congress, without power over the automobile, exerts a power over accident judgments through bankruptcy. And the incidence of the exercise of that power is great, as can be seen from the New Jersey and Boston cases. The problem of state as against federal control in this field is certainly not unique and probably no more acute than in many other fields. Yet the recognition of the problem as one between stato and nation has great advantages. For then the problem tends to be conceived of not in terms of bankruptcy but of automobile accident judgments. When so considered it calls clearly for a return of tho bankruptcy power to the states.

\section{Medical Costs and Illness}

Sickness and doctors' bills, accidents and hospital charges, illness and unemployment played a major rôle in the Boston and New Jersey bankruptcies.

From studies made by The Committee on The Costs of Medical Care ${ }^{26}$ it appears that the relationship between annual charges for

24. See Report by the Committee to Study Compensation for Automobilo Accidents to the Columbia University Council for Research in the Social Sclences (1932).

25. Cf. e.g., the Massachusetts statute, supra note 23, and the Connecticut statute, CoNN. Gen. STAT. (1930) c. $82, \S 1609$, providing that the commissioner of motor vehicles may require proof of financial responsibility from a porson who while operating a motor vehicle causes property damage to at least $\$ 50$ or injures any person. Failure to provide such proof may result in suspension or revocation of the license and registration.

26. Publication No. 27, THE Cost of Medical Care, The Economic Aspects of the Prevention and Care of Illness, c. XVII.

For comparsion with the Boston figures set forth subsequently in the toxt the following data on 25 of the New Jersey cases are relevant:

$\begin{array}{lccc}\text { Income } & \text { Aver. Annual } & \text { Aver. \% of } \\ \text { Under } \$ 1200 & \text { No. Cases } & \text { Charges } & \text { Annual Incomo } \\ \$ 1200-\$ 2000 & 1 & \$ 1013 & 153 \% \\ \$ 2000-\$ 3000 & 3 & 208 & 12 \\ & 5 & 522 & 20.5\end{array}$


medical care and income of families in communities of 100,000 and over is as follows:

$\begin{array}{cc}\text { Income } & \text { Avcrage Ammual Charges } \\ \text { Under } \$ 1200 & \$ 44 \\ \$ 1200-\$ 2000 & 63 \\ \$ 2000-\$ 3000 & 85 \\ \$ 3000-\$ 5000 & 123 \\ \$ 5000-\$ 10,000 & 214 \\ \$ 10,000 \text { and } \text { over } & 390\end{array}$

In comparison with those data are the following for the Boston bankrupts :

$\begin{array}{ccccc}\text { Avcrage Amnual } & \begin{array}{c}\text { Avcrage So } \\ \text { of Anmual }\end{array} & \begin{array}{c}\text { Avcrage Size } \\ \text { of Fanily }\end{array} \\ \text { Uncome } & \text { No. of Cases } & \text { Charges } & \text { Incomo } & 3.6 \\ \$ 1200-\$ 2000 & 75 & \$ 176 & 26.6 \% & 3.9 \\ \$ 2000-\$ 3000 & 95 & 186 & 12.9 & 4.3 \\ \$ 3000-\$ 5000 & 59 & 270 & 11.1 & 3.1 \\ \$ 5000-\$ 10,000 & 11 & 279 & 7.2 & 3.7 \\ & 9 & 534 & 6.6 & \end{array}$

If the figures from the Committee are taken as a norm, the expenditures by the bankrupt group for medical care are highly excessive especially in the lower three income groups-the charges being four times normal in the lowest income group; three times normal in the second; and about three times normal in the third. The number of cases in the Boston group falling above and below the norm is as follows:

$\begin{array}{ccc}\text { Income } & \text { No. Above } & \text { No. Belono } \\ \text { Under } \$ 1200 & 53 & 22 \\ \$ 1200-\$ 2000 & 63 & 32 \\ \$ 2000-\$ 3000 & 31 & 28 \\ \$ 3000-\$ 5000 & 9 & 2 \\ \$ 5000-\$ 10,000 & 5 & 4 \\ & 161 & -\end{array}$

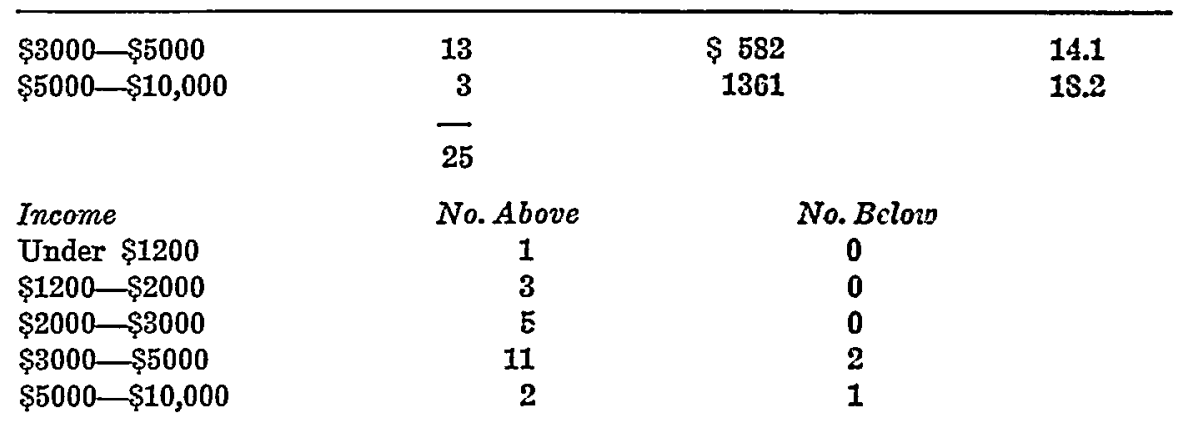


About $64 \%$ of the cases, then, had expenditures for medical care in excess of the average figure supplied by the Committee.

In 53 of the Boston cases they created such a burden of debt that under the pressure of creditors bankruptcy seemed the only way out. In many cases sickness and doctors' bills had a cumulative effect in adding to the burden of debt. But those have not been included here. Also the mere fact that large doctors' bills were incurred has not resulted in classifying the cases in this category. Those expenses have been related to income and in turn to minimum costs of living. In each of them payment would have been impossible without reducing the families to an unbearable poverty level.

In seventeen of the cases members of the family had recoived treatment at clinics and in three cases at veterans' hospitals. But these visits were usually after the crisis had passed and largely were for rather minor matters such as removal of warts from a son's hand. All of them showed a great insistence on obtaining their own doctor or specialist.

In sixteen cases sickness and accidents caused such prolonged absences from work as to make it impossible to pay accumulated debts. These absences ran from four months to four years. The afflictions were many and varied-heart, eyes, stomach, liver and blood pressure. In two cases there was a nervous breakdown resulting in unemployment for several years and confinement in psychiatric wards in hospitals. Another was the case of a bootlegger whose still blew up and incapacitated him for several months.

Deaths with their attendant funeral expenses and preliminary medical expenses accounted for seven cases. The balance were instances of illness of wives and children, some continuing over a long period of years, others ending in a major operation.

The average of the liabilities was $\$ 1747$, the range being from $\$ 221$ to $\$ 8900$.

Consumption credit played not an unimportant rôle in the bankruptcies in this group. $\$ 5220$ was owed to loan companies; $\$ 4613$ on instalment accounts; and $\$ 15,152$ to retailers on open account. The total of $\$ 24,985$ was $27 \%$ of all the liabilities in those cases. Out of the total of debts owed loan companies in all cases $8 \%$ was owed by the cases of this group; $9.6 \%$ in case of instalment debts; and $15 \%$ in case of debts to retailers on open account.

In 16 of the cases the debts owed loan companies and retailers on open and instalment account were $50 \%$ or more of all the liabilities; and in 6 of the cases they were all or practically all of the liabilities. A number of the loans were made to pay doctors. Most of the retail debts were absolute necessities. 
The husband of housewife 0459 had been ill and unable to work for two and one-half years. She had been able to find only part time employment during the last year, her earnings being $\$ 5$ a month. She was in arrears $\$ 660$ in rent. The balance of her $\$ 1000$ liabilities were for necessities of life. In addition to her husband she supported an aged father.

Truck driver 0079 had rather steady employment earning $\$ 1500$ a year. He had seven children, all totally dependent. He said it was impossible to meet the ordinary living expenses on less than his salary. There was no evidence of extravagance. His rent was only $\$ 150$ a year. His total liabilities were $\$ 685$ and his assets zero. He owed $\$ 80$ back rent, $\$ 350$ for furniture purchased on instalment and $\$ 255$ for groceries and clothes. His bankruptcy was traceable to the sickness of his wife. She had a nervous breakdown two years ago and her medical expenses were $\$ 300$ a year. He had moved six times the last year. This was due to his wife's "nervous spells" when she insisted she could not stay longer in a particular tenement. Creditors finally summoned him into the Poor Debtor Court and to escape citation for contempt he filed the petition.

Travelling salesman 0126, 65 years old, had two dependents. He had been making about $\$ 3000$ a year up to three years ago. At that time he became seriously ill with high blood pressure and had to quit the road. He was unable to work for a year and a half. Since then he had been working quite regularly in a shoe store for $\$ 35$ a week. His bills were $\$ 1000$, all incurred during the year and a half of his illness. All but $\$ 150$ was owed retailers for necessities of life. These creditors had attached his wages and he was in danger of losing his job.

Case 0695 had steady employment and made $\$ 2100$ a year. He supported five children and a wife. He lived very modestly. But when a child became sick he went in heavily for specialists. He was not satisfied with one and called another, and so on. He had also consulted a free clinic in Boston but apparently was not satisfied with that. To pay the doctors, the landlord and grocers had to wait. On going into bankruptcy he owed one specialist $\$ 180$, the landlord $\$ 120$ and the grocer $\$ 200$.

In contrast are the New Jersey cases. There only four bankruptcies resulted from illness or excessive medical costs.

\section{Unemployment-Reduction of Income}

The incidence of unemployment was considerable in the Boston bankruptcies. About half were employed less than full time during 
the year preceding bankruptcy. About 5\% (14) were unemployed during the entire year. The numbers are as follows:

\begin{tabular}{|c|c|c|}
\hline \multicolumn{3}{|c|}{ Employment } \\
\hline & Boston & New Jorsey \\
\hline Full time & 150 & 87 \\
\hline Over one-half but less than full & 65 & \\
\hline One-half & 24 & \\
\hline Less than one-half & 19 & \\
\hline None & 14 & 6 \\
\hline & $\overline{272}$ & $\overline{93}$ \\
\hline
\end{tabular}

The unemployment of most was due to general business conditions; of some to age, poor health, inefficiency, etc. Further, there were many employed full or part time whose salaries had been reduced. These factors alone are not significant unless related to costs of living. Accordingly, an analysis was made of the effect of unemployment or reduction of salaries on costs of living and in turn on bankruptcy. At best the results may be solely rough estimates but they approximate the real situation existing.

In 56 of the Boston cases bankruptcy was brought on by unemployment or reduction of salary. Classification of these cases is not without difficulty. Unemployment because of sickness has not been included. Nor have those cases been included where income was reduced but the standard of living was not scaled down accordingly, it being possible to make such adjustment without falling below minimum standards of subsistence. Only cases have been included where the reduction of income reduced the families to such a low poverty level of living as to make it impossible for them to meet the estimated minimum costs of living.

Six of these had received aid from local charities, cities, and the state, usually in the form of coal, clothing and food but in one case in cash from the state aid compensation fund. ${ }^{27}$

As a rule these 56 were cases where a struggle to pay had been made. The debts on the whole dated back from two to eight years. Bankruptcy was chosen as the way out to protect what income the debtors then had or which they soon hoped to get. There was a fear in the minds of these people either that what they needed for subsistence would be taken from them by garnishment or that their employers-present or prospective-being irritated at trusteeships would fire them and employ less involved employees.

In over half of the cases (32) the debts were under $\$ 1000$. All but twelve of the remainder (24) were under $\$ 2000$. The average of

27. Mass. Gen. Laws (1932) c. 1184. 
the liabilities was $\$ 1987$, the range being from $\$ 185$ to $\$ 11,000$. Consumption credit was not conspicuous in these cases. $\$ 1679$ was owed to loan companies; $\$ 13,199$ on instalment purchases; and $\$ 15,894$ to retailers on open account. The total of $\$ 30,772$ was $27 \%$ of all the liabilities in those cases. Practically all of it was owed for necessities of life. Out of the total debts owed loan companies in all cases only $2.6 \%$ was owed by the cases of this group; $27 \%$ in case of instalment debts; and $17 \%$ in case of debts owed retailers on open account.

In 18 of the cases the debts owed loan companies and retailers on open and instalment account were $50, \%$ or more of all the liabilities; and in 6 of the cases they were all or practically all of the liabilities.

Of the New Jersey cases only 6 came into bankruptcy as a result of accumulation of debts during periods of unemployment.

As an emergency measure the exercise by Congress of the bankruptey power for aid and protection of unemployed debtors might well be justified if states had not acted and the need were pressing. But as unemployment is more and more recognized as a problem for long term planning by states, it seems highly desirable to have the bankruptcy power vested in the states so as to make possible its flexible use as a part of particular schemes for lessening the shock and socializing the risk of unemployment.

\section{MIiscellaneous}

Twenty-four of the Boston cases hardly belong in any classification of wage earners or salaried people. These men had once been in business, had been unsuccessful and over a period of years had been attempting to pay the old business debts without success. These debts ranged from $\$ 50$ to $\$ 50,000$. The average debt was $\$ 12,030$. The incentive and occasion for bankruptcy varied somewhat from case to case. And in a few, subsequent debts contributed to the pressure on the debtor. But in practically all of the cases, all of the liabilities were from the previous business. Of the New Jersey cases there were 11 directly related to a previous business. A study of these cases then would entail a study of the businesses which failed. This was not done.

In the few remaining Boston cases a wide variety of claims and judgments were involved: one, for conversion; one, for assault and battery; one, for malicious prosecution; one, for a judgment of $\$ 1,340,000$ for damages for negligence of the bankrupt as director of a corporation; two, judgments on the sale of goods contested by the bankrupt on the ground of fraud; one, a judgment for legal services rendered; six, liabilities on accommodation indorsements 
coupled with other factors such as unemployment, illness, etc.; and five, domestic difficulties.

Three of the domestic cases involved alimony which, though not dischargeable in bankruptcy, ${ }^{28}$ is provable to the extent that it is in arrears. ${ }^{29}$ The debts in these cases for the most part were obligations incurred by the wife, which the bankrupt felt under no moral obligation to pay. In all but two of the cases the debts were so large and the income so small that it was clear the bankrupt could hardly havo avoided bankruptcy.

\section{Collection Methods}

Collection methods are one of the most conspicuous examples of the variability of conditions from state to state which may well have an important bearing on the type of bankruptcy act needed for the protection both of creditors and debtors. They have been discussed elsewhere in this symposium. ${ }^{30}$ Little is lmown respecting their incidence in bankruptcy. The groups of salaried bankrupts from New Jersey and Boston, however, throw some light on the operation of various collection devices in those two states and, conversely, the functioning of bankruptcy to relieve the pressure exerted by creditors through them. The collection methods involved are body executions and supplementary process, attachment and garnishment, and wago assignments.

By statute in Massachusetts a defendant in a civil action (except slander or libel) may be arrested on mesne process on affidavit of the plaintiff and proof to the satisfaction of the court that, inter alia, the defendant intends to leave the commonwealth; the defendant has no property in the commonwealth which can be reached and which is sufficient to satisfy any judgment; and an examination of the defendant will disclose property to be held as security for a judgment. ${ }^{11}$

After judgment the creditor may file an application for supplementary process. A summons is issued requiring the judgment debtor to appear and submit to an examination relative to his property and ability to pay. The court may dismiss the proceedings if on examination of the debtor it finds he has no non-exempt property and

28. In re Pyatt, 257 Fed. 362 (D. Nev. 1918); Bankruptcy Act, § 17.

29. Heimberger v. Joseph, 55 F. (2d) 171 (C. C. A. 6th, 1931).

30. See Sturges and Cooper, Credit Administration and Wage Earnor Banliruptcies (1933) 42 YALE L. J. 487, 502 et seq.

31. Mass. Gen. Laws (1932) c. 224, §§ 1-13. Provisions for bail on mesne process are set forth in Mass. Gen. Laws (1932) c. 226. See Paine v. Kolloy, 197 Mass. 22, 83 N. E. 8 (1907) ; Morton's Case, 196 Mass. 21, 81 N. E. 860 (1907). As to arrest on execution in a civil action see MASS. GEN. LAWS (1032) c. $224, \S 6$. 
is unable to pay the judgment in full or by partial payments. Or on being satisfied of the debtor's ability to pay it may order payment in full or by instalments, after allowing the debtor out of his income a reasonable amount for the support of himself and his family. Failure to obey an order of court constitutes contempt punishable by a fine of not more than $\$ 20$ or by imprisonment for not more than thirty days. $^{32}$ These are the proceedings in the Poor Debtor Court discussed in detail in an accompanying article. ${ }^{33}$

In New Jersey the writ of capias ad satisfaciendum may, with certain specified exceptions, be issued without a judge's order, and as a matter of course. ${ }^{34}$ The exceptions are judgments founded upon contract, express or implied; but in such case the writ will issue in some instances as in bailable causes. ${ }^{36}$ Thus it has been held that in an action of tort the writ will issue as a matter of course as under the English practice at the time of the separation of the colonies and without violation of the constitutional provision ${ }^{30}$ against imprisonment for debt. 37

On the other hand the writ of capias ad respondendum in tort actions is restricted to actions founded on seduction, outrageous battery or mayhem; actions to recover damages for the misconduct or neglect of public officers; or in special causes for holding defendant to bail. ${ }^{38}$ In contract actions it is restricted in general to cases of

32. MASS. GeN. LatyS (1932) c. 224 , §§ 14 et seq.

33. Nehemkis, The Boston Poor Debtor Court-A Study in Collection Procedure (1933) 42 YALE L. J. 561.

34. Kintzel v. Olsen, 73 Atl. 962 (N. J. L. 1909). For regulations of issuance of the writ in district courts see N. J. Cosip. STAT. (1910) p. 2006; Mresserer v. Vannerman, 63 N. J. I. 535, 42 Atl. 806 (1899). See generally HanRs, Plrading \& Practice in Netw Jersey (N. J. Law Sehool Press, 1926) ch. XX, sฐ 648-651.

35. N. J. Conip. Stat. (1910) pp. 4109-10. For cases where the writ was not allowed to issue, see Carroll v. Mickens, 145 Atl. 620 (N. J. L. 1929); Breitheelser จ. Dallas, 87 N. J. L. 362, 94 Atl. 307 (1915); Es parte Clark, 20 N. J. L. 648 (1846). On allowance see Wire v. Browning, 20 N. J. L. 364 (1845); Kipp v. Chamberlin, 20 N. J. L. 656 (1846). As to decrees in chancery see N. J. Cosrp. STAT. (1910) p. 427.

36. Art. I, § 17: "No person shall be imprisoned for debt in any action, or on any judgment founded upon contract, unless in cases of fraud ..." The cases of fraud include not only instances of fraudulent creation of the debt but also subsequent attempts to defeat the creditor's recovery of it by the ordinary process of the law. Ex parte Clark, supra note 35.

37. Kintzel v. Olsen, supra note 34. The court said: "It follows that, since substantially all actions might be begun by capias and a ca. sa. was authorized in every such case, the latter writ ordinarily would issue as matter of course." But see GILBERT, THE LAW of EXECUTIONS (1763, pp. 58 et scq.; 3 BL. Cous. c. XIX; 2 Co. INST. c. xxiii (1681).

38. N. J. Conip. Stat. (1910) p. 4068.

On special cause to hold defendant for bail, see Hufty v. Wilson, 78 N. J. L. 241, 74 Atl. 137 (1909); Hand v. Nolan, 136 Atl. 430 (N. J. L. 1923) where the 
fraudulent concealment or conveyance of assets, or where the debt was fraudulently contracted. ${ }^{30}$ Thus an order to hold to bail was discharged in an action to recover damages as a result of an assault and battery committed by defendant's reckless driving of an automobile.40 The court said: "To me it seems quite clear that in order to constitute an outrageous assault and battery, the act or acts complained of must be of a character akin to mayhem, and must be malicious." 41

Of the 107 New Jersey bankrupts of the salaried class only two had been arrested on a capias, and this was a capias ad satisfaciendum issued after judgments arising out of automobile accidents. These judgments constituted practically all of the bankrupts' liabilities. In one other case the judgment creditor had threatened to obtain a $c a$. sa. and the petition was filed to prevent it. In no cases had a capias ad respondendum been issued.

There were two cases in the Boston group where arrest on mesne process had been made, each to prevent the debtor leaving the state. And there were two where the debtor had been committed to jail for contempt for failure to make instalment payments to the judgment creditor as ordered by the Poor Debtor Court. One was committed for five days; one for seven. It so happened that neither was a case of fraud or questionable practices of the debtor. One debtor was reduced to poverty by unemployment; the other was ill and overburdened by a load of debts, partly medical, accumulated during the illness. If any default under a court order was justified, these were. Clearer cases of misfortune cannot be imagined. It seems somewhat ironical that out of the debtors available for commitment these two should have been chosen.

About a third of the 301 Boston bankrupts (106) had been summoned in the Poor Debtor Court. All but 37 of these had filed their petitions in bankruptcy immediately on service of the summons. In each of the 37 cases the court had made orders to pay. All but 3

court said, "Special reasons ordinarily cited are non-residence of the defendant, or facts and circumstances from which it may be inferred that the defendant may not be in the jurisdiction to answer to a judgment when rendered." And it has been said that special cause must be shown even in cases of outrugcous battery or mayhem. Jacobs v. Costanzo, 136 Atl. 807 (N. J. Misc. 1927). Contra: Keegan v. Carhart, 106 N. J. L. 30, 147 Atl. 841 (1929). See generally Harris, op. cit. supra, note 34 , ch. VI.

39. N. J. Comp. STAT. (1910) p. 4069. Cf. Leventon v. Davison, 102 N. J. I. 144, 130 Atl. 632 (1925). For cases granting the order see Polhemus v. Melides, 96 N. J. L. 105, 113 Atl. 593 (1921).

40. Haglich v. Ceverlere, 105 N. J. L. 521, 146 Atl. 591 (1929). For other cases denying it, see Hand v. Nolan, supra note 38; Siris v. Bialy, 136 Atl. 431 (N. J. L. 1927).

41. Haglich v. Ceverlere, supra note 40 , at $523,524$. 
of these were orders to pay in instalments, running from $\$ 1$ a week up. In each of the 37 cases a default had been made and therefore the debtors were in contempt. But a capias had been issued in but two cases and as noted above those two debtors had been committed. In no case was a fine imposed.

For the most part the effect of bankruptcy upon body executions is clear. By section 9 of the Bankruptcy Act it is provided that

"A bankrupt shall be exempt from arrest upon civil process eicept in the following cases: (1) when issued from a court of banliruptcy for contempt or disobedience of its lawful orders; (2) when issued from a State court having jurisdiction, and served within such State, upon a debt or claim from which his discharge in bankruptcy would not be a release, and in such case he shall be exempt from such arrest when in attendance upon a court of bankruptcy or engaged in the performance of a duty imposed by this Act."

Somewhat similar provisions are contained in General Order XXX.42

It is generally held that pursuant to section 9 of the Bankruptcy Act and General Order $\mathrm{XXX}$ a person against whom body execution has issued by reason of a debt dischargeable ${ }^{13}$ in bankruptcy may be released from imprisonment by writ of habeas corpus on filing of a voluntary petition in bankruptcy ${ }^{44}$ or at least on adjudication. ${ }^{45}$ The Federal court in Massachusetts has so held. ${ }^{40}$ Likewise a stay may be had where the proceedings may result in the arrest or imprisonment of the bankrupt. ${ }^{47}$ And where before and at the time of the adjudication the bankrupt was confined in New Jersey under a capias ad satisfaciendum at the instance of a creditor having $\mathbf{a}$ dischargeable debt, habeas corpus was granted.48 Such relief is

42. See also General Order XII, giving the referee power to afford protection against arrest; and $\S 11$ of the Banlruptcy Act providing for stays.

43. Contra as to debts not dischargeable; In ro Marcus, 104 Fed. 331 (D. Mass. 1900), aff'd, 105 Fed. 907 (C. C. A. 1st, 1901); In ro Pyatt, supra note 28.

44. Ex parte Margiasso, 242 Fed. 990 (S. D. N. Y. 1917) (judgment for automobile accident).

45. Bissing v. Turkington, 113 Conn. 737, 157 Atl. 226 (1931); People ex rel. Taranto v. Erlanger, 132 Fed. 883 (S. D. N. Y. 1904); United States v. Sheriff, 52 F. (2d) 903 (E. D. N. Y. 1931); In re Komar, 234 Fed. 378 (N. D. N. Y. 1916); In re Madigan, 254 Fed. 221 (S. D. N. Y. 1918); Turgeon V. Emery, 182 Fed. 1016 (D. Me. 1910). Contra: In re Claiborne, 109 Fed. 74 (S. D. N. Y. 1901).

46. Ex parte Harrison, 272 Fed. 543 (D. IIass. 1921) (voluntary petition and immediate adjudication). Under the bankruptcy act of 1867 ace Miorse v. Dayton, 125 Mass. 47 (1878); Stockwell v. Silloway, 100 Mass. 287 (1868); Everett v. Henderson, 150 IIass. 411, 23 N. E. 318 (1890).

47. In re Grist, 1 Am. Bank. Rep. 89 (1898).

48. Bloomingdale v. Dreher, 31 F. (2d) 93 (C. C. A. 3d, 1929). 
not conditioned on the granting of or even application for a discharge. ${ }^{49}$ In this connection it should be noted that a judgment upon a claim for negligent injury, including injuries arising out of automobile accidents, is a "debt" which can be proved and is discharged by bankruptcy proceedings and therefore comes within the protection of section 9.50 By statute in Massachusetts,

"If a person arrested on mesne process or on execution becomes an insolvent debtor under the laws of this commonwealth or a bankrupt under the laws of the United States, he shall be discharged upon his application to a district court in the county where the arrest was made, after such notice as the court shall order." 51

In absence of such statute it has been held that while application for habeas corpus may be made to the federal courts, comity suggests that it be made in the first instance to the state court. ${ }^{52}$ But that is not a requirement.

Hence under these rules the two New Jersey debtors arrested on a ca. sa. and the two Boston debtors arrested on mesne process were clearly entitled to release on adjudication of bankruptcy.

Commitments for contempt are not so clear. It is generally held that a stay of the collection of a judgment for a dischargeable debt by means of a contempt proceeding, ostensibly intended only to aid such collection comes within section 9 of the Bankruptcy Act. But if the order of contempt was intended as a punishment and not to assist merely in the collection of the debt, section 9 is held not to. extend immunity to the bankrupt against commitment.53 Nor is immunity from arrest granted as respects contempts for failure to pay claims not dischargeable in bankruptcy, such as alimony, ${ }^{\text {b4 }}$ for

49. Bissing v. Turkington, supra note 45 .

50. Ex parte Margiasso, supra note $44 ; E x$ parte Harrison, snpra noto 46 ; Bissing v. Turkington, supra note 45; Lewis v. Roberts, 267.U. S. 467 (1925). Contra as to pure tort claims for unliquidated damages: Schall v. Camors, 251 U. S. 239 (1919). On claims for "willful and malicious injuries" not discharged, see Tinker v. Colwell, 193 U. S. 473 (1904).

51. MASS. GEN. LAws (1932) c. 224, § 29.

52. United States ex rel. Scott v. McAleese, 93 Fed. 656 (C. C. A. 3d, 1800).

53. In re Pyatt, supra note 28. In re Hall, 170 Fed. 721 (S. D. N. Y. 1009); In re Koronsky, 170 Fed. 719 (C. C. A. 2d, 1909). But the language in some cases is sufficiently broad to make no such distinction but to warrant donial of a stay in all cases of contempt committed prior to adjudication. In ro Francisco, 245 Fed. 216 (N. D. N. Y. 1917).

54. In re Frity., 152 Fed. 562 (E. D. N. Y. 1907); In re Houston, 04 Fed. 119 D. Ky. (1899); Wagner v. United States, 104 Fed. 133 (C. C. A. 6th, 1900). Alimony to become due is not a debt dischargeable in bankruptcy. $\$ 17$ Bankruptcy Act; In re Pyatt, supra note 28. This was so held by the Supremo Court even prior to the 1903 amendment expressly so providing. Wetmore $v_{r}$ 
fines for contempt, 55 or willful and malicious injuries. ${ }^{\circ 5}$ But in cases of alimony, ${ }^{57}$ as in other cases, ${ }^{58}$ it seems that the court may in its discretion restrain such proceedings. And such stay is effective to restrain the state court from punishment for an alleged contempt committed before adjudication. ${ }^{59}$

Prior to 1931, habeas corpus had been granted by the Federal court in Massachusetts in cases of commitments by the Poor Debtor Court whether for contempt ${ }^{60}$ or not. ${ }^{01}$ But in a case in 1930, petition for habeas corpus was dismissed for the reason that the sentence of commitment for contempt was punitive, the debtors having been defiant, dishonest and deserving of punishment. ${ }^{02}$ And in 1931, in an unreported case rendered without opinion, the court refused habeas corpus in a contempt case from the Poor Debtors' Court apparently making a blanket ruling for all such commitments. It may

Markoe, 196 U. S. 68 (1904); Audubon v. Shufeldt, 181 U. S. 575 (1901). Contra: In re Houston, supra. But in Heimberger v. Joseph, supra note 29, it was held that claims for alimony in arrears partly represented by notes were provable.

A discharge in bankruptcy to be effective must be pleaded. Thus where after adjudication the bankrupt is sued on a provable debt and at no time from the commencement of the action until entry of judgment and issuance of exccution a plea of bankruptcy or discharge in bankruptcy is made, the judgment may be enforced by arrest and is not open to collateral attack. Herschman v. Justices of the Municipal Court, 220 Mass. 137, 107 N. E. 543 (1915). Cf. In ro Lockwood, 240 Fed. 161 (E. D. N. Y. 1917).

Similarly in other collateral attacks on the judgment rendered, as in suits in another jurisdiction on the judgment where for the first time discharge is pleaded in bar. Dimock v. Revere Copper Co., 117 U. S. 559 (1886). But enforcement of such judgments have been enjoined in equity. Badger v. JordanMarsh Co., 256 Mass. 153, 152 N. E. 92 (1926).

As to procedural devices to contest a decree of contempt for failure to comply with an order of the Poor Debtors' Court after a discharge in banluruptcy sea Commissioner of Banks v. Tremont Trust Co., 267 MIass. 331, 166 N. E. 848 (1929). Cf. In re Lockwood, supra.

55. People v. Sheriff of Kings Co., 206 Fed. 566 (E. D. N. Y. 1913).

56. In re Stone, 278 Fed. 566 (N. D. N. Y. 1922).

57. Wagner v. United States, supra note 54.

58. In re Fortunato, 123 Fed. 622 (S. D. N. Y. 1903); In re Adler, 144 Fed. 659 (C. C. A. 2d, 1906) the court saying, at 661: "It would seem, therefore, that it was the duty of the court to stay the contempt proceedings if the claim were one which could be proved and discharged in bankruptey; surely to do so was within the sound discretion of the judge." The order restrained a judgment creditor in the state court from attempting to enforce its judgment by proceedings to punish the bankrupt for contempt.

59. In re De Lany \& Co., 124 Fed. 280 (N. D. N. Y. 1903); In re Fortunato, supra note 58. See Bankruptcy Act $\$ 11$.

60. Boston American, Oct. 24, 1930.

61. Es parte Harrison, supra note 46 .

62. Fed. Misc. Civ. Docket, No. 4306. 
well be that a presumption that such commitments are punitive is justified. Yet it would seem to be no more than a presumption, and certainly in cases of stays of proceedings in citation for contempt it could not be said that all citations for contempt in the Poor Debtor Court are primarily or presumptively for punishment rather than in aid of collection of debts. The way the court operates negatives any such presumption. ${ }^{03}$

Thus it seems clear that adjudication in bankruptcy is ground for a stay against citation for contempt of the Poor Debtor Court, but probably not grounds for habeas corpus. The matter was academic as respects the two debtors who had been committed because they had already served their sentences when the bankruptcy petition was filed. Their petitions were to prevent other contempt proceedings. As respects the others from the Poor Debtor Court who were in contempt but who had not been arrested, it is clear that bankruptcy afforded immunity from arrest. After adjudication it seems clear that no arrest can be made in such proceedings. ${ }^{04}$

Assignments of wages are strictly regulated by statute in Massachusetts. ${ }^{65}$ Assignments to secure a loan of less than $\$ 300$ must, inter alia, exempt $\$ 10$ a week, be accepted in writing by the employer, and if the assignor is married, consented to in writing by the wife. Such approval by employer and wife are required in the case of other assignments of wages; and in addition an exemption of three-fourths of the weekly earnings or wages of the assignor is necessary. These strict provisions doubtless are the reason why no wage assignments had been filed against any of the wage earners here studied.

Garnishment in Massachusetts is regulated by statute providing that all personal actions (except malicious prosecution, slander, libel, assault and battery, and replevin) may be commenced by trustee process by serving and summoning any person as trustee of the defendant in the action. ${ }^{66}$ The person summoned as trustee must disclose what goods, effects or credits of the defendant were in his hands when the writ was served on him. ${ }^{67}$ The goods, effects or credits of the defendant in possession of the trustee are attached and

63. See Nehemakis, op. cit. supra nate 33 .

64. See National Surety Co. v. Reed, 262 Mass. $372,374-5,160$ N. E. 281, 282-3 (1928).

65. MASS. GEN. LAWS (1932) c. 154. It should, however, be noted that Massachusetts has held, contrary to the weight of authority, that a wago assignment given before bankruptcy is a lien preserved by $\$ 67$ of the Bankruptcy Act and not affected by the discharge in bankruptcy of the assignor. Citizens Loan Assoc. v. Boston \& Maine Rr., 196 Mass. 528, 82 N. E. 696 (1907).

66. Mass. Gen. LAWS (1932) c. $246, \S 1$.

67. Id. at $\S 10$. 
held to respond to final judgment as if they had been attached upon an original writ of attachment. ${ }^{68}$ To this there are several exceptions or qualifications. If wages for personal labor or services are attached for a debt other than for necessaries furnished the defendant or his family, an amount not exceeding twenty dollars is exempt; but in case of a debt for necessaries, where the writ contains a statement to that effect, then an amount not exceeding ten dollars is exempt." Furthermore it is provided that no person shall be adjudged a trustee by reason of money or any other thing due from him to the defendant, unless it is, at the time of service of the writ upon him, due absolutely and without any contingency. ${ }^{\circ 0}$ But by other provisions a writ once served upon a trustee may be served again and with the same effect as if it had not been previously served. ${ }^{71}$

Thus wages not due at the filing of the writ cannot be collected; ${ }^{72}$ but other writs may be served on successive pay days. Successive services, however, do not have the cumulative effect of reducing the amount of exemption by treating all services as but one attachment. Thus the debtor is entitled to the stated exemption at each service of the writ. ${ }^{73}$ Employment contracts have been worked out, however, so as to give immunity to the employer as trustee under the statute. One contract provided that the employer "may pay all wages earned at such times and in such parts as it may from time to time elect"; that the employee should not leave the employ "unless this contract

68. Id. at $\S 20$.

69. Id. at $\$ 29$.

70. Id. $\$ 32$. By this same section wages for personal labor or services of the wife or minor children of the defendant are exempt, as are wages of a seaman but not a fisherman.

71. Id. at $\S 8$.

72. Hadley v. Peabody, 13 Gray 200 (1859) (The principal defendant was employed for a year at a salary of $\$ 1,000$ payable quarterly; service of process was made about the middle of the quarter. It was held that there was no debt to trustee) ; Fellows v. Smith, 131 MIass. 363 (1881) (Employer had claim against employee-collection agent for unremitted balances exceeding amount of wages due); O'Brien $\nabla$. Collins, 124 Miass. 98 (1878). And see cases collected 56 A. L. R. 638 et seq. (1928) ; 20 L. R. A. (n. s.) 912 (1909). And see Wyman v. Hichborn, 60 Miass. 264 (1850).

But where the Commonwealth is the employer it cannot be trusteed. Dewey $v$. Garvey, 130 Mass. 86 (1881). For further cases see 56 A. L. R. 602-624 (1928); 40 L. R. A. (n. s.) 218 (1912) ; 46 L. R. A. (n. s.) 301 (1913). But cities, towns, and counties may be summoned as trustees. Hooker v. MicLennan, 236 MIass. 117, 127 N. E. 626 (1920). But not where an assessor's right to compensation from a town for services rendered was based upon statute and not upon an express or implied contract with the town. Walker v. Cook, 129 Ifass. 577 (1880).

73. Hall $\nabla$. Hartwell, 142 IIass. 447, 8 N. E. 333 (1886). Accord: Howard Coal Co. v. Savage, 116 Me. 115, 100 Atl. 369 (1917). And see Sullivan v. Hadley Co., 160 Mass. 32, 35 N. E. 103 (1893); L. R. A. 1917D 899-900. 
is terminated by mutual assent, or as herein provided, without giving thirty days' notice thereof, and working out such notice"; and that "all wages earned shall at all times be held liable to entire forfeiture to said company, in case of leaving without first giving and working out the full time of such notice." At the date of the process the employee was at work under the contract, not having given notice of intent to leave. The employer had no fixed days for paying employees but usually paid each month a "part of their wages, retaining the balance under the contract." The employer claimed that all wages earned by the defendant were held by it under the contract and that they were not absolutely due, being subject to the forfeiture. The wages earned since the last payment amounted to $\$ 19.46$, for which sum the trustee was charged. It did not appear whether or not the balance of wages retained by the employer on pay days was more than nominal. The court discharged the trustee. ${ }^{74}$ Ames, J. said:

"We cannot say that such a contract, fairly and deliberately made, is unreasonable, oppressive, or contrary to public policy. It imposes no burden upon the workman that he cannot at any time remove by giving the stipulated notice. It secures the employer against interruption of his business by the abrupt withdrawal of help. And so far as it has a tendency to prevent the expense and annoyance of trustee suits, it is a convenience which, in the absence of fraud, defeats no legal right and interferes with no legal claim of any other party." 75

The same result has been reached in Massachusetts ${ }^{70}$ and in many other jurisdictions ${ }^{77}$ where wages are paid in advance. In the Massachusetts case the employer by the contract of employment agreed to pay defendant monthly in advance. This advance was not made directly to the employee but to a third person who was treasurer of the trustee. The court in holding the trustee not liable said it made no difference whether at the time of the trustee process the employee had actually received the salary from the treasurer. In either event the employer's liability had been discharged.

As a result of trusteeships 84 of the 301 Boston bankrupts filed their petitions. The wages had been trusteed usually many times, the greatest number being 40 in one year. Seven of the bankrupts had been discharged by their employers as a result of trusteeships. And in six of the cases the employer had threatened discharge unless the trusteeships ceased. One was a large company in Boston which had

74. Potter v. Cain, 117 Mass, 238 (1875). Cf. Faulkner v. Waters, 28 Mass، 472 (1831).

75. Potter v. Cain, supra note 74, at 240-241.

76. Callaghan v. Pocasset Mfg. Co., 119 Mass. 173 (1875).

77. See cases collected 56 A. L. R. 629 et seq. (1928). 
adopted the policy of permitting two trusteeships but threatening discharge if more than two were had. So far as could be learned this policy was rather strictly carried out.

Of the remaining Boston cases the pressure of creditors had not advanced to legal methods of collection. In 10 cases, however, suits had been started and in 16 judgments had been rendered.

Attachments, or garnishments, of wages in New Jersey before judgment are considerably more restricted than in Massachusetts. There must be (1) a liquidated claim arising ex contractu and an affidavit of the creditor that the debtor absconds from his creditors and is not resident in the state at the time; or that the debtor is not a resident of the state; or (2) an order for attachment by a judge or commissioner upon proof by affidavit of fraud which would warrant an order for a capias ad respondendum. ${ }^{78}$ Another statute, broader in scope, includes actions in tort and unliquidated contract claims, applies to resident as well as non-resident defendants and requires a judicial order to precede the attachment. The instances most applicable here where attachment may be had are in cases (1) where there are facts sufficient to hold defendant to bail and (2) where the cause of action arises in the state, the defendant absconds or is a non-resident, and summons cannot be served. ${ }^{70}$ Excepted from attachment are wages due a non-resident employee in suits by a nonresident creditor; ${ }^{80}$ and wages of soldiers and sailors who served in the World War in suits to collect debts contracted prior to the war. ${ }^{81}$

But after judgment has been recovered ${ }^{82}$ and execution returned wholly or partly unsatisfied and wages to the amount of eighteen dollars or more per week are due the judgment debtor or shall become due him the judgment creditor may obtain from the court, without notice to the judgment debtor, an order directing execution against the wages. This execution on presentation to the employer becomes a lien and a continuing levy upon the wages in an amount

78. N. J. CoMp. STAT. (1910) p. 133. For statutory regulations of capias ad respondendum, see N. J. Comp. Stat. (1910) pp. 4068 et seq., Hisor v. Vandiver, 83 N. J. L. 433, 85 Atl. 181 (1912); Williams \& Davis, Inc. v. Davis, 147 Atl. 337 (N. J. L. 1929).

79. N. J. Conip. Stat. (1910) p. 4076. That the two statutes are supplementary and cumulative see Hotel Registry Realty Corp. v. Stafford, 70 N. J. I. 528, 57 Atl. 145 (1904); and see Henry v. Freeman, 145 Atl. 107 (N. J. L. 1929). See generally HARRIS, op. cit. supra note 34 , ch. VII.

80. Id. at 133 , changing the rule of Leonard v. Lawrence, 32 N. J. L. 355 (1867).

-81. N. J. Laws (1920) c. 304, p. 552.

82. For aplication of the provision to district courts see 8 N. J. LAws (1924) c. 204, p. 431; N. J. CoNIP. STAT. (Cum. Supp. 1911-24) $\$ 61-204 \mathrm{~K}$. As to jurisdiction of District Courts, see N. J. CoMp. StaT. (1910) p. 1962; N. J. Liw (1926) c. 225. 
not exceeding $10 \%$ of the income unless the income is in excess of $\$ 1,000$ a year. In the latter event the judge "may order a larger percentage." 83 Only one execution, however, against the wages may be satisfied at one time. ${ }^{84}$ In interpreting the statute the Court of Errors and Appeals has said:

"The statute is in derogation of the common law rights of the debtor. It takes from him, without notice, and without a hearing, property which, except for the statute, is exempt from execution. It is, therefore, necessary for the creditor and the court in attempting to enforce the right given by the statute to follow its provisions strictly." 85

In that case the income (rentals from realty) of the judgment debtor exceeded $\$ 1,000$ a year and the lower court ordered an execution to issue against the rentals to the full amount until the judgment was paid. In affirming a judgment vacating the order, the court said:

"The order under review entirely disregards this important right of the judgment debtor to retain for his own use and benefit all of the wages, earnings, salary, \&c., which shall come to him from time to time, except at percentage thereof to be fixed by the court or judge, and paid from timo to time upon the execution." 86

What review will be had of the discretion of the judge in fixing the percentage of wages to be paid on execution is not clear. But apparently the judge in fixing the percentage must take into consideration minimum costs of living of the debtor. As stated in one case:

"This judicial discretion is vested in the judge, so that not all the wages shall be garnished and the debtor be at once deprived of his wages, but

83. N. J. LAwS (1915) c. 266, p. 470 , as amended; N. J. LAws (1916) c. 113, p. 242 ; N. J. Comp. Stat. (Cum. Supp. 1911-24) § 71-9L. The statute applies to decrees in chancery as well as to judgments at law. White v. White, 94 N. J. Eq. 278, 120 Atl. 419 (1923). See generally Harris, op. cit. supra note 34, ch. $\mathrm{XXI}, \S \S 629-630,646$.

84. But it has been held that this limitation applies to executions from tho same court. Thus where the Supreme Court has made an order, the District Court at the same time could levy pursuant to the same provision under its sct. Berkowitz v. First District Court, 8 N. J. Misc. R. 847, 152 Atl. 847 (1930).

The statute permits an execution against the salary of a municipal officor. Petersen v. Jersey City, 89 N. J. L. 93, 97 Atl. 963 (1916) (policeman); Oatjon v. Hintemann, 91 N. J. I. 429, 106 Atl. 213 (1916). See generally 56 A. L. R. 602 (1928). Prior to this statute the rule was contra. Spencer v. Morris, 67 N. J. L. 500,51 Atl. 470 (1902). On the constitutionality of such statntes see Cavondor v. Hewitt, 145 Tenn. 471, 239 S. W. 767 (1921) and cases collected 22 A. L. R. 760 (1923).

85. Trapp v. Brown, 93 N. J. L. 171, 173, 107 Atl. 413, 414 (1919).

86. Ibid. 
that, in case of the debtor and his family, only such portion of the debt shall be paid, from time to time, as will leave the debtor's family unimpoverished." 87

Prior to judgment, attachment of wages can be had only in the rather exceptional case. And after judgment wages can be reached only upon execution pursuant to statute. ${ }^{88}$

In the New Jersey salaried group there were no cases of bankruptcy following an attachment of wages. And there were but four cases where the judgment creditor had obtained execution on wages. In one of these cases the salary was so irregular as to make the execution in wages particularly severe on the debtor. In two other cases a judgment creditor had threatened wage execution. In the balance the pressure of creditors was not through the law.

Assignments of wages, under the Small Loan Act in force in New Jersey at the time of this study, had to be accepted in writing by the employer, and consented to in writing by the wife. ${ }^{83}$

Assignments of wages for other purposes are with one exception subject only to the general rules of common law and equity which, with certain restrictions, ${ }^{30}$ permit the assignment, equity vesting the "equitable title to the money in the assignee." or The exception is a statute making unlawful assignments of wages upon which the assignee receives directly or indirectly more than the legal rate of interest upon the amount of wages due. But there is excluded from the act assignments made for the payment of goods or merchandise sold the employee for full value or for any professional service rendered him. ${ }^{32}$

But in the salaried group of bankrupts from New Jersey there were no cases where wage assignments had been filed or used as collection devices by the creditors.

87. Margarum v. Mioon, 63 N. J. Eq. 586, 590, 53 Atl. 179, 181 (1902).

88. Ibid.

89. N. J. LAwS (1914) c. 49, p. 79; N. J. Comp. Stat. (Cum. Supp. 1911-24) $\S 35-19$. Further restrictions were imposed by the Small Loan Act of 1932. By that act assignments of wages to secure such loans must, inter alia, be in writing and signed by both husband and wife and are valid as respects $10 \% 0$ of the wages. N. J. LATrS (1932) c. 62.

90. As for example the rule prohibiting the assignment of unearned salary of a public officer. Schwenk v. Wyckoff, 46 N. J. Eq. 560, 22 Atl. 259 (1890) (retired U. S. army officer).

91. See Brindge v. Atlantic City Policeman's Benefit Assoc., 75 N. J. Eq. 405, 72 Atl. 435 (1909), aff'd, 77 N. J. Eq. 272, 79 Atl. 686 (1910).

92. N. J. Comr. STAT. (1910) pp. 3048-49. But it has been said that this statute does not affect the validity of the contract but only renders the assignce liable to prosecution for misdemeanor. Rosenbusch $\nabla$. Frey, 5 N. J. Misc. Rep. 312, 136 Atl. 711 (1927). 
The picture then which these cases give of the relationship between bankruptcy and various collection devices is of interest. As respects wage assignments the incidence is nil in both districts. Likewise body executions and, in New Jersey, attachments and execution on wages are quite inconspicuous. In contrast are the prominence of trusteeships of wages and supplementary process in the Poor Debtor Court in Boston. Those two together were the direct occasion for filing of the petition in two-thirds of the cases. If this sample of cases is representative, the toll over a period of years is enormous.

\section{Can Wage Earner Bankrupts Pay?}

Collection devices have an important bearing on the problem of providing a moratorium for wage earners and of devising a machinery which will enable them to pay their debts. There are two aspects of this problem: (1) can wage earner bankrupts pay their debts if given adequate time? and (2) assuming some machinery for amortization is advisable, should it be vested in federal or state agencies?

It is common knowledge that the bulk of wage earner bankrupts have no assets whatsoever, above their legal exemptions, which creditors can reach for satisfaction of their claims. ${ }^{03}$ This was in general true of the Boston and New Jersey cases as shown by the following summary:

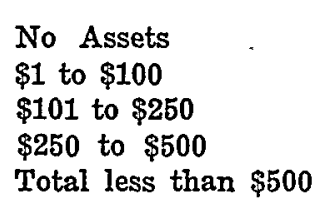

$\begin{array}{cc}\text { Boston } & \text { Now Jersoy } \\ 79.4 \% & 34.5 \% \\ 9.3 & 10.2 \\ 2.6 & 14.0 \\ 2.3 & 11.2 \\ 93.6 & 69.9\end{array}$

Both Boston and New Jersey cases, particularly the latter, had highly inflated or padded assets due to the listing of so many equities in real estate. The total liabilities of the Boston wage earners was $\$ 4,108,075$; the assets (not as appraised but as scheduled), $\$ 259,559$. For New Jersey the figures were $\$ 2,508,290$ for liabilities; and $\$ 330,983$ for assets.

93. Thus for the fiscal year ended June 30,1930 , in all wago earnor cases for the entire country the following were the asset groups:

$\begin{array}{lc}\text { No assets } & 84.90 \% \\ \$ 1 \text { to } \$ 100 & 9.46 \\ \$ 101 \text { to } \$ 250 & 2.70 \\ \$ 250 \text { to } \$ 500 & 1.11 \\ \text { Total less than } \$ 500 & 98.17\end{array}$

See Strengthening Procedure in the Judicial System, supra noto 4, at 7. And see Douglas and Marshall, A Factual Study of Bankruptcy Administration and Some Şugestions (1932) 32 CoL. L. REv. 25. 
The total of $\$ 6,616,365$ seems at first blush a staggering load of debt for 408 wage earners to carry. In this connection it should be noted that these cases do not present the picture of people contracting debts and thereupon rushing off to bankruptcy to be relieved of them. Financial embarrassment for less than a year was present in but $13 \%$ of the Boston cases. In $66.4 \%$ of the cases this financial embarrassment had continued for two years or more and in $46.2 \%$ for three years or more. The average was three and a half years; the median somewhat less than three years. ${ }^{01}$

Yet in spite of these enormous debts and small assets and the relatively long period of time during which these debtors have endeavored to extricate themselves from difficulty, it is frequently suggested that they could pay if they would or that they could and would if only a moratorium were declared. Creditors of the Boston and New Jersey bankiupts almost invariably stated such opinion apropos of their contention that bankruptcy was too obviously a sanctuary for the protection of recalcitrant and dishonest debtors. In the same connection, suggestions have been made from time to time that some proration or amortization provision be embodied in the Bankruptcy Act making it possible for wage earners to pay off their creditors under the protection of the court. Such provision has been included in the bankruptcy bill prepared by the Department of Justice and introduced in the 72d Congress, ${ }^{95}$ whereby a wage earner ${ }^{85}$ may be allowed to amortize or fund his debts over a period of not more than two years.97

In the report accompanying the proposed bill the Department of Justice gave the following reasons ${ }^{88}$ in support of the provision:

"Our inquiry has led us to the following conclusions: (1) That most wage earners who fall into debt desire to pay their debts in full and wish to avoid the stigma of bankruptcy; (2) that they are driven into bankruptcy chiefly by garnishments and other attachments, even in the midst of an effort to pay in installments; (3) that at least a third of the wage earners who are now forced into bankruptcy and released from their debts could, if given time and protection, pay their creditors in full; (4) that if

94. Fürth, The Critical Period Before Banlinuptcy (1932) 41 YALE L. J. 853, $855,863$.

95. Sen. Doc. 3866, 72d Congress, 1st Sess.

96. Id. at $\S 1$ (a) (27), defining wage earner as an individual "who worlss for wages, salary or hire."

97. Id. § 75. The two year period is of course arbitrary. But it seems more desirable than a longer period. Certainly an early determination of ability to pay is necessary. To prolong the period of amortization seems undesirable not only in view of the administrative tasks involved but also in light of the vicissitudes of life for the average wage earner.

98. Strengthening of Procedure in the Judicial System, supra note 4, at 80. 
the law offered such relief without stigma, a still larger number of wage earners, who now resort to loan companies in an effort to stave off their creditors and gradually get into debt beyond their capacity to pay, would find a means of relief at a comparatively early stage of indebtedness."

In support of the third reason given above, the Report went on to say: ${ }^{00}$

“. . An analysis of the wage-earner bankruptcies closed in the flscal year 1930 in the 10 districts having the largest number of these bankruptcies revealed that at least 12 per cent of these wage earners had debts of under $\$ 250$; that at least 12 per cent had debts of from $\$ 250$ to $\$ 500$; and that at least 25 per cent had debts of from $\$ 500$ to $\$ 1,000$. Thus, in about half the cases . . . the debts were $\$ 1,000$ or less. In at least another 24 per cent of the cases the debts were from $\$ 1,000$ to $\$ 2,000$; so that, all told, nearly three fourths of these bankrupts owed from $\$ 2,000$ on down.

"It is hard to believe that many, if not most, of these bankrupts, with small debts could not have paid them in installments. . . .

"While the study has not been completed, a preliminary examination of the referees' reports and of case history reports submitted by business organizations, shawed that in innumerable cases the ratio of the monthly income of wage earner bankrupts to their total debts was at lenst 1 to 6. ..."

It is of interest to speculate as to the probable success of amortization, under the proposed bankruptcy amendment, of the debts of the salaried group of Boston and New Jersey bankrupts. In the first place it would be hazardous to rely on the foregoing estimates without knowing not only the amount of obligations but also the income of the debtor and the number of people dependent on him for support. Without the latter, estimates would be unreliable. The fnct that the ratio of monthly income to total debts was at least 1 to 6 is likewise of little significance without knowing if the monthly income after deducting enough for subsistence left any balance for debts.

From a study made in 1927 by the National Industrial Conference Board of costs of living in twelve industrial cities it is reported that the average minimum cost of maintaining a fair American standard of living for the family of an industrial worker, his wife and two children living in Boston was $\$ 1,627.33 .100$

Writing in 1925 Paul H. Douglas stated four main standards or levels of living applicable to the working class family of five.101 Poverty level.102 "While costs necessarily vary from city to city it

99. Id. at $82-83$.

100. The Cost of Living in Twelve Industrial Crties, op. cit. supra noto 16 , at 51 .

101. Douglas, Paul H., Wages and The Famity (1925) 6-6.

102. Id. at 5: "On this standard, the family is not on a basis of permanent seif-support, and exists because of inroads which it makes upon its own health 
is probable that it would cost a family of five between $\$ 1,000$ and $\$ 1,100$ to live on this scale in the larger American cities at the present time." 103 (2) Minimum-of-subsistence level. ${ }^{104}$ "At the present time, families of five in the larger American cities would need somewhere between $\$ 1,100$ and $\$ 1,400$ to live on this level." 105 (3) The subsistence-plus, or the minimum health-and-decency-level. ${ }^{100}$ "Such a standard would seem to cost from $\$ 1,500$ to $\$ 1,800$ in most of the larger American cities." 107 (4) The minimum-of-comfort-level. ${ }^{103}$ "The cost of such a standard for a family of five at the present time would probably range somewhere between $\$ 2,000$ and $\$ 2,400$ in our larger cities." 109

\section{A later study concluded that}

"In 1928-29, according to the estimates of competent economists and social workers, a family of five living in urban communities in the United States, needed from $\$ 1,000$ to $\$ 1,500$ to maintain a minimum subsistence standard of living. On the whole, the estimates indicate that $\$ 1,200$ or $\$ 1,300$ is needed rather than less. . . . In the same period the cost of maintaining a minimum comfort standard of living was in.the neighborhood of $\$ 1,800$ to $\$ 2,000 . " 110$

or upon its supply of furniture and goods. The family's dietary is generally appreciably below the standard of 3,300 calaries which are needed for an adult male at moderately heavy labor. The family is badly overcrowded and has no resources with which to meet any unexpected expense."

103. Ibid.

104. Ibid: "Families living on this standard receive enough to maintain themselves physically, but not enough to meet the major emergeneies of illness, accidents, old age, etc., or to enjoy social pleasures that cost money. Since such families will in practice tend to insist upon securing some of these pleasares, they will in consequence tend to be somewhat undernourished and appreciably overcrowded."

105. Ibid.

106. Id. at 6: "A sufficient surplus is accumulated to enable the standard family decently to house itself in five rooms or, at the worst, in four, to purchase food with sufficient calories to meet the needs of the family, and to buy cheap but neat clothing. In addition, a modest balance would be available for recreation and for sundries."

107. Ibid.

108. Ibid: "It is this that is commonly thought of when one speals of the American standard of living.' A much more liberal standard of clothing, housing, and of sundries now becomes possible. Adequate insurance against the industrial risks may be purchased, and an appreciable amount of amusement and recreation may be enjoyed. . . . Such a level of living, while desired by all, has, however, been attained by only a small proportion of the industrial wage earners."

109. Ibid.

110. Reed, The Ability to Pay for Medical Care, v-11, Publication No. 25 of The Committee on the Costs of Medical Care. 
For comparison with the foregoing studies are the statistics collected by the Bureau of Labor Statistics in 1918 and 1919,11 for Boston and for 92 industrial centers. From these data ${ }^{112}$ it is seen that at least $65 \%$ of the families in Boston and in the entire group of 92 industrial centers had incomes below that set by the National Industrial Conference Board. About 23\% were on the "poverty level" of Paul H. Douglas. About $65 \%$ were on the "minimum-ofsubsistence level" or lower. Only about 8 or $9 \%$ were on the "minimum-of-comfort level." And in the study previously quoted it is said,

"With due allowance for the fact that the average family of low income probably has somewhat less than 4.4 members instead of 5 members, and that the costs of living may be lower in rural areas than in cities, one may conservatively estimate that in 1928 not less than 8 per cent of all families of more than one person in this country were unable to afford a minimum subsistence standard of living. . .. . This standard of living ("minimum comfort") was beyond the reach of at least one-third of the population of the country." 113

Of course these studies are not strictly comparable. The methods probably varied and the periods of time studied were different. Adjustments for changing price levels and wage scales, of course, would have to be made if they were to be used in 1933. And further adjustments for different sized families would have to be made if they were employed in an amortization scheme. For example, in the Boston and New Jersey studies the family of five ${ }^{114}$ or family of four ${ }^{115}$ did not predominate, though the average was about four.

111. Cost of Living in the United States, op. cit. supra noto 11. "This investigation covered white families in 92 cities or localities in 42 states, the cities varying in size from New York to small country towns of a few thousand population."

112. Id. at $5,11$.

113. Reed, op. cit. supra note 110 , at v-15.

114. Using the categories of Paul H. Douglas, the thirty-three families of five in Boston were distributed as follows: (1) Poverty level-11; (2) Minimum-of-subsistence level-7; (3) Subsistence Plus level-4; (4) Minimum-ofComfort level-7; (5) In excess of minimum-of-comfort-4.

115. Of the fifty-six families of four in Boston, 28 had incomes below the minimum set by the National Industrial Conference Board; 27 had incomes above that minimum.

As reported by the 1930 census, of the $29,904,663$ families in the United States $7.9 \%$ were one-person families; $23.4 \%$, two-person families; $20.8 \%$, three-per'son families; $17.5 \%$, four-person families; and $12 \%$, five-person families. The median size of family for native whites was 3.34 ; for foreign born whites, 3.74. See U. S. Daily, Nov, 25, 1932, at 1717 . 
The various sized families were

\begin{tabular}{ccc} 
31embers & $\begin{array}{c}\text { Size of Faum } \\
\text { Boston }\end{array}$ & Neto Jcrocy \\
& \multicolumn{2}{c}{ No. Cascs } \\
1 (bachelor) & 27 & 14 \\
2 & 53 & 19 \\
3 & 42 & 19 \\
4 & 56 & 23 \\
5 & 33 & 12 \\
6 & 27 & 6 \\
7 & 12 & 1 \\
8 & 6 & 1 \\
9 & 5 & 0 \\
10 & 3 & 0 \\
12 & - & 1 \\
& -264 & 96 \\
& Average 3.8 & Average 3.3
\end{tabular}

Yet in spite of these limitations the other studies are both useful and suggestive in considering the theoretical and practical aspects of the proposed amortization provision.

At once there is raised a problem of considerable social and economic importance. What standard of living should be adopted? Though the system is not made compulsory, nevertheless, as has been pointed out, ${ }^{118}$ wage earners may well be under pressure of creditors to amortize; and excessive optimism may well lead to attempts to do so. If the standard of living is at the minimum subsistence level, should the administrator in charge permit it to be reduced to the poverty level for a two year period in order to pay creditors? In dealing with such cases would that class of debtor be better served by being led directly to the bankruptcy execution block? Obviously these are questions that cannot be answered by legislative mandate. They are matters of administrative discretion. As such they are of vital importance.

In analyzing these bankruptcies the cases have been divided into income groups. Included in income are contributions from other members of the family. The income is that for the entire year preceding the date of the filing of the petition in bankruptcy. It may be added that no follow-up of these cases has been made to ascertain

116. Douglas and Marshall, op. cit. supra note 93.

In this connection it is interesting to note the whole-hearted support given the amortization provision of the proposed bankruptcy amendments by certain retail credit organizations. One circular states that it will give wage earners "a chance to save their names and play fair with creditors by paying their obligations out of earnings;" and that it will "throw the protection of the United States Department of Justice around the Retail Creditor" who it is insisted now "takes it on the chin." 
if the income increased or decreased after bankruptcy. Against income has been placed the number of dependents (so as to estimate roughly the cost of living) and the amount of indebtedness. From indebtedness have been deducted assets at their scheduled value. Common sense, not formulae, supplies the answer in the vast majority of the cases.

The results obtained in the salaried group of Boston bankrupts are set forth below.

\begin{tabular}{|c|c|c|c|c|}
\hline \multirow[b]{2}{*}{ Income Group } & \multicolumn{4}{|c|}{ AMORTIZATION } \\
\hline & No. & Probable & Doubtful & Impossiblo \\
\hline No Income & 14 & 0 & 0 & 14 \\
\hline$\$ 500$ or less & 11 & 0 & $\mathbf{0}$ & 11 \\
\hline$\$ 1000$ and over $\$ 500$ & 51 & 0 & 0 & 51 \\
\hline$\$ 1500$ and over $\$ 1000$ & 66 & 3 & 18 & 45 \\
\hline$\$ 2000$ and over $\$ 1500$ & 65 & $\mathbf{5}$ & 17 & 43 \\
\hline$\$ 3000$ and over $\$ 2000$ & 51 & 8 & 14 & 29 \\
\hline$\$ 4000$ and over $\$ 3000$ & 9 & 1 & 1 & 7 \\
\hline Over $\$ 4000$ & 10 & 3 & 0 & 7 \\
\hline & $\overline{277}$ & $\overrightarrow{20}$ & $\overrightarrow{50}$ & $\overline{207}$ \\
\hline Income unknown & 24 & & & \\
\hline Percentage & & $7.3 \%$ & $18 \%$ & $74.7 \%$ \\
\hline
\end{tabular}

In the "doubtful" column have been placed those cases where mathematically amortization would be possible but where (1) collateral circumstances indicate the debtor would be very averse to undertaking an amortization due to his dislike for the dominant creditor or his general attitude towards his debts; (2) the health of the debtor coupled with his low income makes successful amortization unlikely and the wisdom of beginning it dubious; or (3) an attempt at amortization would in all probability reduce the standard of living to such an extent as to place the families involved on a poverty or at least a bare subsistence level. The following are examples of cases in this classification. Two debtors owed $\$ 401$ and $\$ 407$ respectively. One with four dependents had an income of $\$ 1400$; the other with three dependents had an income of $\$ 1320$. In case of the former, amortization, if elective, probably would not be undertaken for the reason that the debtor went into bankruptcy to get rid of debts incurred by an extravagant wife whom he had just divorced. In the other it might be attempted. But to do so would reduce this family pretty close to a poverty level. In another case the debtor earned $\$ 1000$, had one dependent and owed $\$ 485$. To amortize the debt in two years would require deduction of $\$ 20$ n month from his salary leaving but $\$ 60$ for two people to live on. Theoretically amortization might be undertaken. In view, however, of this bankrupt's precarious health it would seem unwise, if not impossible, to do it. In a higher income group was a wage earner 
who owed $\$ 490$, earned $\$ 2200$ and was the head of a family of seven totally dependent on him. It is obvious he would refuse to amortize even though he could since the entire amount was owed on an accommodation indorsement for a friend and there was ill will existing between the debtor and the creditor.

In the "probable" column are cases where mathematically amortization is possible without undue pressure on the debtor and where no collateral circumstances appear which would make it seem likely that the debtor would be unwilling. It cannot, of course, be said with certainty that in each of these cases the debtor would under an elective system be willing. Examples of cases classified here are as follows. One, who owed $\$ 494$ had no dependents and an income of $\$ 1800$, could probably amortize; as could another who owed $\$ 400$, had one dependent and earned $\$ 1600$. In a higher income group was a wage earner who owed $\$ 434$, earned $\$ 2700$ and had two dependents. Another was a skilled worker having one dependent, earning $\$ 3000$, and owing $\$ 1600$.

In the "impossible" column have been placed those cases where the number of dependents and the ratio of debts to income make a two year period of amortization out of the question. Here are included all of the cases in the three lower income groups. In the "no income" group the average indebtedness was \$6091. Only 4 had debts of less than $\$ 500$, the smallest being $\$ 50$. In the "\$500 or less" group the average indebtedness was $\$ 3599$ and in only 2 cases were the debts less than $\$ 500$. And in the next group the average indebtedness was $\$ 10,536$. In only 3 cases was the indebtedness $\$ 500$ or less. Other cases classified here ranged from instances where the income was $\$ 1200$ a year, the debts $\$ 600$ and the number of dependents 6 , to situations where the salary was from $\$ 4000$ to $\$ 12,000$ a year and the debts were many hundred times that sum.

A detailed analysis for the small group of New Jersey cases will not be presented here. The results of the analysis, however, are as follows:

\begin{tabular}{|c|c|c|c|c|}
\hline \multirow[b]{2}{*}{ Income Group } & \multicolumn{3}{|c|}{ AMIORTIZATION } & \multirow[b]{2}{*}{ Impossiblo } \\
\hline & No. & Probable & Doubtful & \\
\hline No income & 5 & & & 5 \\
\hline$\$ 500$ or less & 1 & & & 1 \\
\hline$\$ 1000$ and over $\$ 500$ & 3 & & & $\overrightarrow{3}$ \\
\hline$\$ 1500$ and over $\$ 1000$ & 10 & 1 & & 9 \\
\hline$\$ 2000$ and over $\$ 1500$ & 16 & 1 & $\mathbf{2}$ & 13 \\
\hline$\$ 3000$ and over $\$ 2000$ & 17 & 2 & 3 & 12 \\
\hline Over $\$ 3000$ & 5 & & & $\mathbf{5}$ \\
\hline & $\overline{5 \pi}$ & 一 & - & - \\
\hline Income unknown & 50 & 4 & 0 & 48 \\
\hline Percentage & & $8 \%$ & $10 \%$ & $82 \%^{\circ}$ \\
\hline
\end{tabular}


The results are not materially different from those in the Boston group. It is of interest that in the four cases where amortization was probable, three had liabilities composed entirely of automobile accident judgments and one of accommodation liability. Whather such claims would be so willingly amortized as ordinary mercantile claims may, well be doubted. Therefore, only a more liberal classification than that used in the Boston cases permits the addition of these four cases to the "probable" column.

The extent to which the Boston and New Jersey cases were affected by the current depression is impossible to conjecture. As previously noted the New Jersey cases came into bankruptcy in the fall and winter of 1929. and the spring of 1930 , before the full force of the depression was felt, while the Boston cases came in during the fall and winter of 1930, and the spring of 1931. Even so, as has been seen, the percentages of probable amortizations do not vary materially;

If these cases are representative, the estimate of the Department of Justice must be greatly revised. From these cases it certainly is not "hard to believe that many, if not most, of these bankrupts with small debts could not have paid them in installments." A probable danger in any amortization scheme is that those in the doubtful column would be subjected to considerable pressure on the part of their creditors to attempt amortization. As has been seen, in most of these cases amortization would mean reduction of the standard of living to an extremely low level. Should that be done? It seems that not even an attempt should be made. The social cost is likely to be too great. Whether or not it would be done would depend, of course, on the quality of administration under the act and the willingness or reluctance of the officials to turn the screws as hard as possible. As a practical matter, if it were done, it would probably mean the admission into the scheme of a host of cases, marginal at the very best, which soon after admission would default and increase enormously the administrative task. In view then of these various factors, it would seem unwise to count on the bulk of the doubtful column for the grist of the mill.

The debts of these wage earners from Boston and New Jersey were somewhat larger than those of the wage earner bankrupts studied by the Department of Justice. ${ }^{117}$ The distribution was as follows:

117. Strengthening of Procedure in the Judicial System, supre note 4, nt 82-83. The group of Boston and New Jersey cases included in the table are the 284 to which amortization was applied. 


Liabilities
Under $\$ 250$
$\$ 250$ to $\$ 500$
$\$ 500$ to $\$ 1000$
$\$ 1000$ to $\$ 2000$

No.
6
12
78
81

$\%$

2.1

4.2

27.5

28.5
To Dopt. of Justice

(approz.)

12

12

25

34

Thus, while the Boston and New Jersey groups had about $62 \%$ of cases with liabilities below $\$ 2,000$, the Department of Justice group had about $73 \%$.

It is true, of course, that most of the probable amortizations came in the group with debts of less than $\$ 2,000$. The distribution was;

$\begin{array}{lr}\text { Under } \$ 250 & 0 \\ \$ 250 \text { to } \$ 500 & 3 \\ \$ 500 \text { to } \$ 1000 & 10 \\ \$ 1000 \text { to } \$ 2000 & 8 \\ \$ 2000 \text { to } \$ 5000 & 3 \\ & -24\end{array}$

The percentage then of wage earners with debts of less than $\$ 2000$ which probably could be amortized is about $13 \%$. If this group is representative, an increase in numbers of the group to correspond with the figures of the Department of Justice would not substantially increase the percentage of cases where amortization was probable.

As a practical matter the volume of debts which these 24 bankrupts would amortize is almost infinitesimal as compared with the total indebtedness of the entire group. The 24 had liabilities of $\$ 26,971$. The entire salaried group had liabilities of $\$ 6,616,365$. Amortization then would result in the payment of only $.4 \%$ of the entire liabilities of all the bankrupt wage earners. This fact coupled with the further fact that amortization would reach such a small percentage of bankrupts raises serious doubts as to the advisability of instituting such a system for bankrupts. The net seems out of all proportions to the catch.

But these objections are not necessarily conclusive of the case against amortization.

The Department of Justice believes that

"if the law offered such relief without stigma a large number of wage earners who now resort to loan companies in an effort to stave off their creditors and gradually get inta debt beyond their capacity to pay would find a means of relief at a comparatively early stage of indebtedness."

In other words, the wage earner in bankruptcy may represent such an extreme pathological case that what amortization could do for him would be no reliable measure of what it could do for wage earners 
generally. While the wage earner in bankruptcy is helpless and needs the execution block of the discharge, he might have obtained the necessary relief had amortization been available to him months earlier.

Proof or disproof of this is impossible. Are wage earners in bankruptcy typical of wage earner-debtors generally? To what extent could wage earner-debtors effectively employ the amortization scheme? Would the number of cases and volume of debts be too negligible to justify inauguration of some such system?

Answers to these questions are at best guesses. The idea has been so highly regarded as to be incorporated in the draft of the proposed Uniform Municipal Court Act.118 And some twelve of the Ohio municipal courts have had amortization provisions for a number of years. ${ }^{119}$ Perhaps the answer to the questions may be found in the experience of those courts. In absence of that, the only definite and concrete material is that from the files of the American Amortization Company of Chicago, which for a number of years has without aid of statute engaged in such activity. Cases from the files of that company were taken where the debtor had three dependents, i.e., cases of families of four. These debtors were wage earners most of whom were public utility employees. The majority of them earned between $\$ 2080$ and $\$ 2600$ a year. The minimum standard of living was arbitrarily set at $\$ 1500 .{ }^{120}$ The surplus annual income over that sum was assumed to be available for payment of their debts; and a two year period was taken as the term for amortization. The result reached was that $82 \%$ clearly or probably could amortize over a two year period. ${ }^{121}$ The estimate is probably a liberal one as it is by no

118. Uniform Municipal Court Act, Draft Prepared by Professor Hessel D. Yntema.

119. The statute giving such power to the municipal court of Columbus is typical, OHIO GEN. CODE, (Page, 1931) § 1558-54c. In addition the Cloveland Municipal Court inaugurated such a system in 1932 without aid of statute.

120. This is somewhat lower than the estimated standard of living for a family of five in Chicago in 1929 which has been estimated as $\$ 1,938.44$ on tho basis of 1929 prices. These amounts were said to be "the least that are required ... 'for a manner of living that will make possible a high standard of physical, mental, and moral health and efficiency for adults, the full physical and montral growth of children, and provide for their moral welfare." See Reed, op, oit. supra note $110, \mathrm{pp} . \mathbf{\nabla - 1 5}$.

121.

Annual Income

Under $\$ 2080$

$\$ 2080 — \$ 2600$

Over $\$ 2600$

Amortization

Total cases-151

\begin{tabular}{lccr}
\multicolumn{4}{c}{ AMIORTization } \\
Yes & Probable & Doubtful & No \\
15 & 11 & 6 & 10 \\
78 & 4 & & 3
\end{tabular}


means clear that $\$ 1500$ was an adequate minimum for that class of employee. If such cases are common, amortization might well serve a genuine service to this type of debtor. The contrast to the bankruptcy cases is striking. This material, though extremely limited, suggests the possibility of the use of amortization in advance of bankruptcy to serve a function not normally performed by collection devices today.

But granting the desirability of having available for such debtors some legal machinery of amortization, the problem of determining whether it should be vested in federal or state agencies remains. As discussed above, ${ }^{122}$ collection devices available to creditors vary much from state to state. Furthermore, the type of creditor has much to do with the degree of pressure to which the debtor is subjected. ${ }^{123}$ The assumed need for amortization reflects the pressure of creditors - both legal and extra-legal - on debtors with the resultant fear of loss of job, loss of wages, commitment to jail, etc. And control of the business of these creditors as well as control of the collection devices is in the hands of the states not Congress.

Those considerations point clearly to the conclusion that amortization should be under state control as an integral part of the bankruptcy power. The determination of when creditors should be paid, and under what conditions, is but another phase of the decision of when a debtor should be released from his obligations. Both entail much the same process. They call for consideration of types of creditors, the antecedents of the debtor's financial difficulties, his income, dependents and the standard of living which he needs or deserves. By reposing the two powers in one state agency a close coördination of the two functions may be realized. Thus both would become equally effective as agencies of control in various programs of social legislation of the states.

Furthermore, the states, not Congress, have control over the collection devices which creditors may employ. In these collection devices are the beginnings of methods for proration and amortization. ${ }^{124}$ It seems desirable to build on these beginnings and to utilize to the fullest possible extent the administrative procedures and

It should be noted, however, that these employees were of a relatively high income group. Further discussion of these cases and others from the same company is available in Fortas, op. cit. supra note 9.

122. Sturges and Cooper, Credit Administration and Wage Eamer Banliruptcies (1933) 42 YALE L. J. 487, 502-513.

123. Cf. Fortas, Wage Assignments in Chicago-State Strect Furmiture Company v. Armour \& Co. (1933) 42 YALE L. J. 526, passim.

And see Nugent, Forgive Us Our Debts (1932) 16 PERsonas FIN. NETS 5. 124. Sturges and Cooper, Credit Administration and Wage Eamer Banlirupteies (1933) 42 YALE L. J. 487, 517 et seq. 
techniques which states have evolved or with which they have gained experience. The alternative of raising a new and huge federal superstructure to handle a function of some familiarity and experience in the states seems unwise. In conclusion it should be said that when creditors may apply pressure on their debtors and when the debtors may be relieved from such pressure are integral parts of the same problem. The former is and will continue to be a problem for the states since they rather than Congress have control over collection methods. To divide that function between state and nation by allocating to the federal bankruptcy courts the amortization power is but another step towards the division of responsibility with all of the disadvantages of lack of unified control. It would be but intensifying difficulties which have resulted from an exercise by Congress of the bankruptcy power over wage earners and the control of collection devices by the states.

\section{III}

The result of the present system is to superimpose one structure on another with but little articulation between the two. It is not merely that the various policies effectuated through the present bankruptcy act may contravene state policies as expressed by collection devices and many different types of regulation of business, social and economic conditions. The chief criticism is that under the present system the bankruptcy power remains practically unexploited as an agency of public control. It is not to be denied that the fundamental problem suggested by wage and salary earner bankruptcies is an improvement in the management of consumer credit and a rationalization of our economic order. But it is safe to say that many years will elapse until there has developed a more effective control over the flow of credit than we now have. And the time is probably far distant when the unevenness in the economic order will be ironed out, when economic cataclysms will cease, and when the salaried group will have something more than their own resources with which to absorb the shock of industrial displacements, financial disturbances and accidents and misfortunes of life. In other words we will continue to have a great need for some system of bankruptcy to permit escape from unbearable burdens of debt and persistent pressure of creditors that take their toll in lowered standards of living, economic instability and fear and trembling. In planning for these contingencies it seems possible to improve a system so haphazard as the present. Today there is a uniform bankruptcy act for the nation. Yet bankruptcy is not uniform. It never can be until the economic and social problems in various localities are uniform. If the juris- 
diction over wage earner bankrupts is retained by Congress, we will continue to have expressions of national policies on issues that are not national.

One thing a study such as this for the whole nation would reveal would be the essentially local nature of the different conditions revealed. Wage assignments were immaterial in Boston and in New Jersey. Yet they rank high in importance in Chicago. ${ }^{125}$ Likewise, as has been shown, loan sharks are unimportant here; yet their importance to bankruptcy elsewhere is apparent.120 Local practices, credit controls, consumption habits, stability of employment vary much from state to state. These affect wage earner credit both quantitatively and qualitatively. The incidence in each state (and perhaps in different localities in the same state) varies. To some extent at least the need for bankruptcy increases or decreases directly with the increase or decrease in the effectiveness from creditors' viewpoints of the various collection devices. Furthermore, what pressure devices creditors may employ and when debtors may be relieved of that pressure seem to be integral parts of the same problem. What these collection devices are and will continue to be are matters of state control. To articulate them in terms of bankxuptcy and bankruptey in terms of them seems essentially a local problem. At least the problem is an organic whole. And it seems susceptible of better treatment when considered as a local rather than a national one.

Leaving to each state the control over the whole of these many problems would obviate the futility of trying to provide the same mechanism (bankruptcy) for many different or at least varying conditions.

It cannot be supposed that the judgment of Congress is infinitely better than the judgment of those closer to the economic and social problems in the state. It is apparent that bankruptcy performs many functions. It may be serving as a safety valve for the enormous pressure of loan sharks, unemployment, medical costs, etc. Or it may reflect loose credit practices of retailers or the mounting costs of injuries for automobile accidents. These problems are not standard or the same throughout the nation.

Furthermore, Congress, though it had the power, is not going to enter extensively into these fields of regulation. Reviewing the various problems revealed by the Boston and New Jersey bankruptcies it is seen that they are predominantly state, not federal, problems. Housing, home building, loan companies, credit unions, instalment selling, retail credit, unemployment, medical costs, auto-

125. Fortas, Wage Assignments in Chicago-State Strcet Fumiture Company v. Armour \& Co. (1933) 42 YALE L. J. 526.

126. See Nugent, op. cit. supra note 10. 
mobile accidents-all these as between state and nation are essentially the former's. Certainly it is difficult to see in them a primary place for federal programs of control. Perhaps some are not yet ripe for state programs of control. But that by no means earmarks them as being peculiarly appropriate for Federal regulation through the bankruptcy power.

Two questions naturally arise. How would state bankruptcy acts vary from the present federal act if Congress did not exercise its constitutional power? In what way could the bankruptcy power in the hands of the states be made an effective agency of control? To answer these questions in detail is impossible, due to the fact that it would entail a comprehensive program of social legislation for forty-eight states and would call for determination of policies on a host of major social and economic issues. There are, however, several illustrative variations which may be propounded purely as possibilities. To cope with consumption credit conditions and practices in a city like Chicago, a bankruptcy system might be devised which was extremely liberal to the wage earner debtor and which permitted him to be relieved of pressure of creditors with great facility. In an agrarian, rural section, where the problem was to encourage the flow of credit to wage earners, and where the abuses of consumption credit were minor, a bankruptcy system might be devised which was more favorable to the creditors, where discharges were more difficult to obtain, and where bankruptcy was less available. Or, take the problem of automobile accidents. In states where the problem was acute, carrying of liability insurance might receive additional encouragement by denying an automatic discharge of such claims up to a certain amount. Or in case the claim arose out of a violation of a penal provision of the motor vehicle act, that claim might be treated more stringently than the ordinary automobile accident claim. In such cases the filing of a bankruptcy petition might not be allowed to give immunity from arrest. In states, however, where the problem of automobile accidents was not deemed particularly acute, extreme liberality might be shown debtors. In Massachusetts it might be deemed desirable to incorporate the Poor Debtor Court into the bankruptcy court. In that way one agency would perform two closely related functions-the granting of a discharge to hopelessly involved wage earners, and the supervision of a proration or amortization program for those wage earners who could pay, if given time, without impairment of minimum standards of living. Not only would a more expeditious procedure result but there would follow a closer articulation between bankruptcy and collection methods. Similarly, in other states the procedure for garnishment of wages might be incorporated in a bankruptcy system 
which placed all creditors on an equal footing and likewise provided for a discharge to the debtor where the garnishment would work an undue burden on him. By other methods the separate banluruptcy systems might go so far as to segregate for special treatment particular types of creditors-such as unlicensed lenders-and give relief against such creditors more readily than against others.

The foregoing are merely illustrative. The permutations and combinations are innumerable. What prophylactic effect could be obtained by the use of bankruptcy in connection with any one problem is not known. But if the states are given the power to legislate with the use of the bankruptcy power, an agency of control hitherto but little used can be fully exploited in many different programs of social planning.

Two considerations remain. In the first place, where not all assets are within the state the advantages of a national, uniform system of liquidation are obvious. Collection of assets, liquidation, and distribution of dividends are not hampered by state lines. But this problem is not acute in wage earner bankruptcies. As has been seen, about $85 \%$ of them have no assets whatsoever. And judged by the Boston and New Jersey cases, which in this regard are no doubt representative, such assets as there are, are very rarely outside the state. Where creditors are widely scattered throughout the states, a national and uniform system may also have some advantages in making easier the filing of claims and participation in the process of liquidation. But that feature is not present here. The Boston and New Jersey wage earners had very few creditors outside the state. In that regard those cases are no doubt typical as it is difficult to imagine that the run of creditors in wage earner bankruptcies would be other than local. The advantages then of a national system of bankruptcy so frequently mentioned in cases of commercial failures seem inapplicable here. Thus the need for uniformity disappears and along with it, its virtues and advantages.

Secondly, a sudden repeal of the present bankruptcy act, so far as it affects wage earners, would probably be undesirable. Not all states are at present fully prepared to handle expeditiously and equitably the pressing problems of creditors and debtors. Without the aid of the present bankruptcy act, a genuine emergency might face many wage earners. Therefore, the suggestions here made are conceived of as parts of programs for long term planning. A repeal of the bankruptcy act to take effect at the end of a five year period would supply adequate time for the separate states to prepare for the event and to devise systems of bankruptcy consonant with other phases of their legislative programs. ${ }^{127}$ In this connection the

127. Of course, the bankruptcy power in the hands of the states cannot be made retroactive so as to impair obligations of contract. This interim be- 
varied utility of the bankruptcy power should be noted. As an emergency measure it is conceivable that Congress would be justified in employing it for the relief of wage earners during a period of great economic instability provided the states were not giving adequate relief. Furthermore, though Congress relinquished control over wage earner bankruptcies, it might well exercise the bankruptcy power in some situations. It is not a question of complete retention or surrender by Congress. Rather it is a problem of determining in light of the exigencies of particular situations by whom and in what way the bankruptcy power should be exercised.

As to commercial bankruptcies it is by no means clear that the present exclusive jurisdiction of Congress is desirable, although complete surrender of control as in case of wage earner bankruptcies would not be expedient in view of obvious procedural and administrative difficulties. In case of railroads the full possibilities of bankruptcy as a device for their financing and reorganization has as yet not been fully appreciated. The fact of the matter is that the bankruptcy power of the constitution is one of the least exploited constitutional powers. But the realization of its greatest utility is not going to result if Congress continues to assert a primary and exclusive jurisdiction over all bankruptcies irrespective of their types.

In conclusion then it can be said that as respects wage earnex bankruptcies the present system treats the problems piecemeal, with the disadvantages of separation of control between state and nation. With the responsibility placed upon the states it seems likely that there would the sooner eventuate a more effective treatment and control of many problems whose incidence is measured in part by bankruptcy. At least it can be said that with the division of responsibility as exists today haphazard treatment will continue and under the guise of the virtues of uniformity the continuance of the evils of maladjustments will be likely. Not until bankruptcy is thought of as a congeries of problems, such as housing, home buying, small loans, collection methods, unemployment, medical costs, retail credit practices, instalment buying, automobile accidents, etc., rather than as an institution, will more effective control over these problems and their various agencies eventuate. Relinquishment to the states of the bankruptcy power over wage earners increases the probability of the realization of that control.

tween relinquishment of jurisdiction by Congress and assumption by the states can be employed to inaugurate state systems prospectively. In this way such constitutional difficulty could be minimized. There is moreover much to bo said for taking this step at present when the lines of credit are at an exceedingly low ebb. 